\title{
Review of synthetic strategies in the development of oxadiazine scaffolds
}

\author{
Mohammad Arif Pasha*, Sumanta Mondal and Naresh Panigrahi \\ Department of Pharmaceutical Chemistry, GITAM Institute of Pharmacy, Rushikonda, \\ GITAM (Deemed to be University), Visakhapatnam, Andhra Pradesh, 530045, India.
}

\begin{abstract}
Heterocycles containing both oxygen and nitrogen are in a tremendous demand for their immense biological activities. Oxadiazines are the scaffolds shown pleasing activities like antibacterial, antifungal, anthelmintic, anti-inflammatory, locomotor, anticonvulsive, antiviral, antitumor, agricultural, insecticidal, nematocidal, miticidal, neurogenerative disorders like Alzheimer disease, blood disorders like anemia and plant regulation. Multiple syntheses of oxadiazine scaffolds like 1,2,4-oxadiazines, 1,2,5-oxadiazines, 1,3,4-oxadiazines, 1,3,5-oxadiazines have been summarized in the review. Several research chemists are making attempts to discover and introduce the new scaffolds for various diseases ailments in the present scenario. Here we made an attempt to introduce the scaffolds of substituted oxadiazines because a lesser amount of research was carried out on these nuclei.
\end{abstract}

Keywords: oxadiazines, heterocyclic scaffolds, 1,2,4-oxadiazines, 1,2,5-oxadiazines, 1,3,4-oxadiazines, 1,3,5oxadiazines.

\section{Introduction}

Compounds contain nitrogen in their cyclic structure exists numerous biologically active moieties
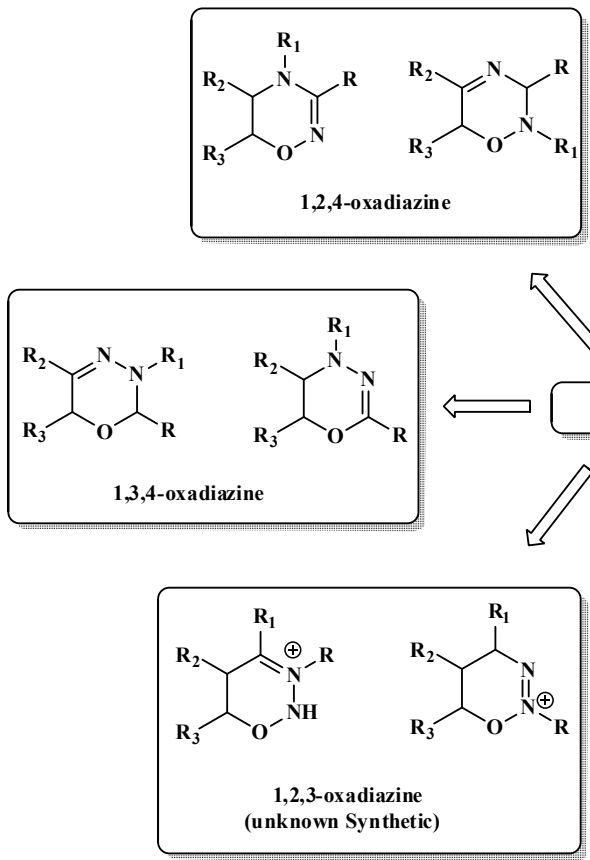

and exhibit numerous application's in chemistry, biology, and other sciences ${ }^{1-6}$. Oxadiazines are the molecules with oxygen and two nitrogen rest in different positions of the cyclic structure.
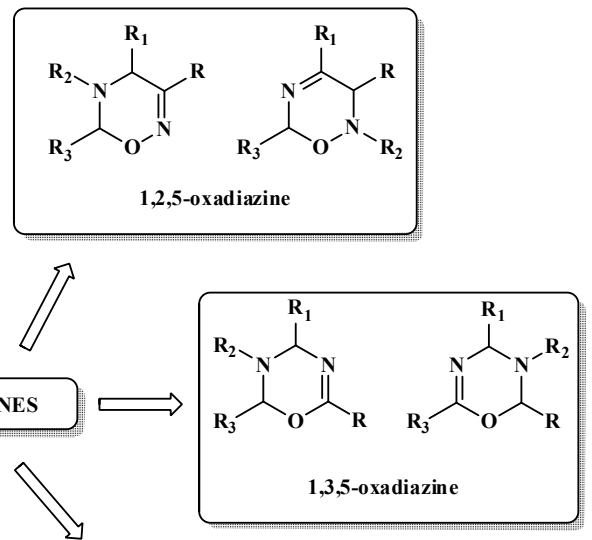

Figure 1. Substituted scaffolds of oxadiazine nucleus

*Corresponding author: Mohammad Arif Pasha Email address : arif.mohdpasha@gmail.com DOI: http://dx.doi.org/10.13171/mjc851907025map 
Oxadiazines have a reflective structure with certain peculiarities in which the molecules of the oxadiazine nucleus are non-planar in the arrangement, and the scaffolds are non-aromatic. The structures of different oxadiazines are 1,2,3-oxadiazine, 1,2,4oxadiazine, 1,2,5-oxadiazine, 1,2,6-oxadiazine, 1,3,4oxadiazine and 1,3,5-oxadiazine depicted in Fig.1. Medicinal chemists developed the various synthetic routes for different oxadiazines and its derivatives for their potential activity towards agriculture and medicin, but so far no synthetic route has been developed on 1,2,3-oxadiazines (except 1,2,3oxadiazine of natural origin) and 1,2,6oxadiazines $^{7-11}$.

\section{Materials and methods}

\section{Natural oxadiazine scaffold}

Nocuolin $\mathrm{A}(\mathrm{NoA}) \mathbf{1}$ which is the merely natural 1,2,3-oxadiazine scaffold obtained from three cyanobacterial strains of Nostoc, Nodularia, and Anabaena. A demonstration has been carried out that NoA has attributes of caspase-dependent apoptosis and moreover it exhibits potent antiproliferative activity against most cell lines, out of which the most effective was found in p53 mutated cell lines ${ }^{12}$.

\section{Synthetic oxadiazine scaffold}

Another natural 1,3,5-oxadiazin-2-one alkaloid ${ }^{13}$ Alboinon 2 isolated from Ascidian Dendrodoa grossularia and its synthetic routes has been developed from protected oxadiazinone $\mathbf{5}$ of acid chloride 3 reacted with $N, N$-dimethylguanidine to form 4 followed by phosgene to attain the desired scaffold 5 (Scheme 1) ${ }^{14}$ and also from BaeyerVilliger oxidation by rearrangement of imidazole 6 by reacting with $m$-chloroperbenzoic acid to get alboinin 2 (Scheme 2).

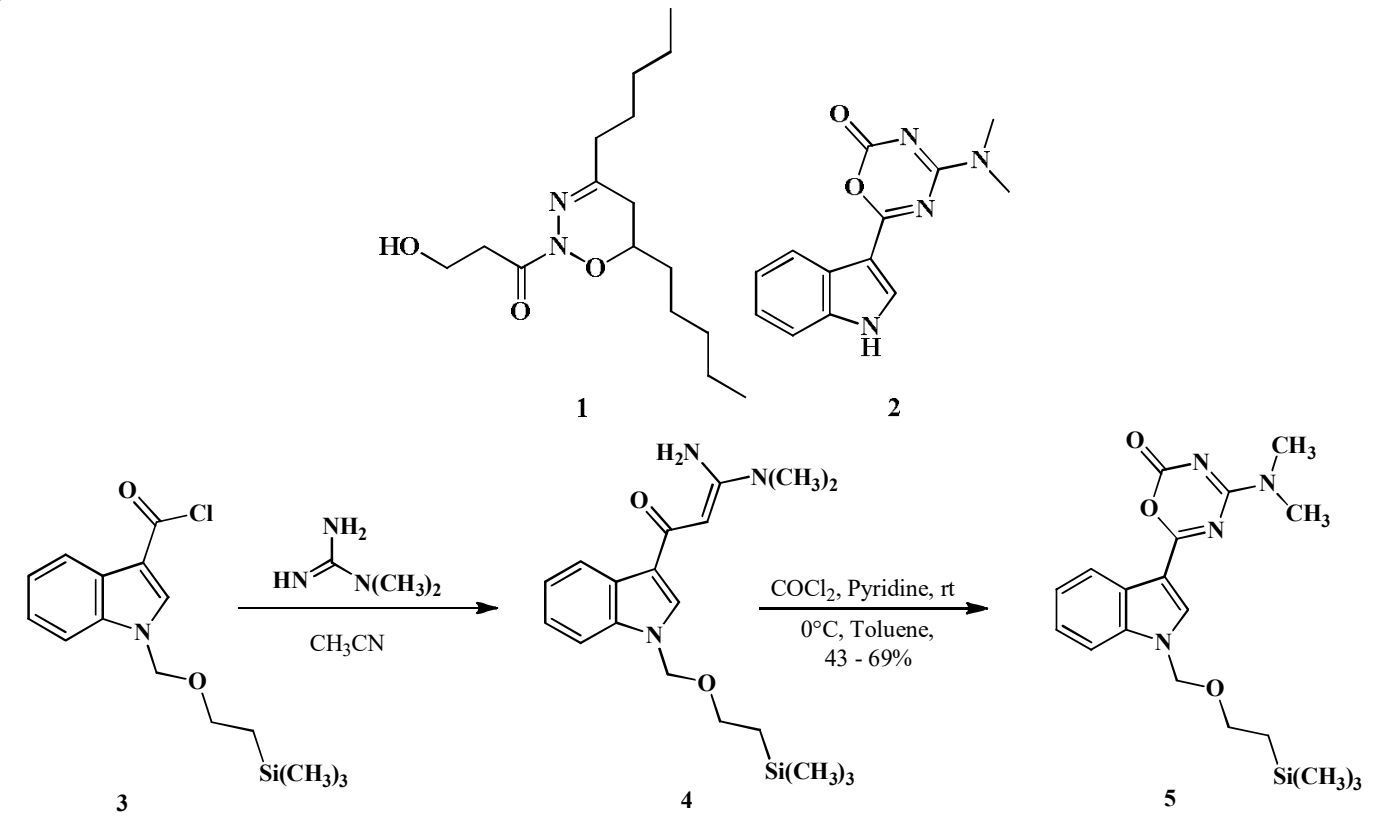

Scheme 1. Synthesis of Alboinon from acid chlorides<smiles>CN(C)C1=NC(=O)C(c2c[nH]c3ccccc23)=N1</smiles>

6

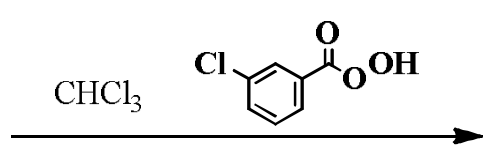

Dark 1h, $\mathrm{NaHCO}_{3} 80 \%$

Baeyer-Villiger<smiles>CN(C)c1nc(-c2c[nH]c3ccccc23)oc(=O)n1</smiles>

2

Scheme 2. Synthesis of Alboinon by Baeyer-Villiger Oxidation

Indoxacarb 7 which is a 1,3,4-oxadiazine scaffold pesticide developed by E.I. du Pont de Nemours and company commonly referred to as "DuPont" which is an American company. It is active against lepidopteran larvae ${ }^{15}$, and it blocks insect neuronal sodium channels ${ }^{16}$. 


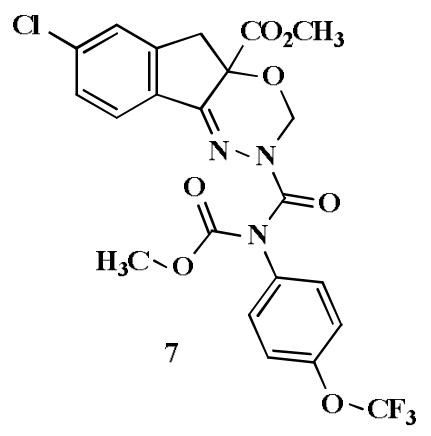

Indoxacarb

Synthesis of Indoxacarb takes place in two steps one from 9-fluorenylmethyl chloroformate 8 reacting with hydrazine hydrate to form the acid hydrazide derivative 9 further reacts with methyl 5-chloro-2hydroxy-1-oxo-2,3-dihydro- $1 H$-indene-2-carboxylate $\mathbf{1 0}$ in the presence of tosylic acid to form a Schiff base 11 undergoes cyclization at hydroxyl group with a nitrogen of an amide to form 1,3,4-oxadiazine dicarboxylate 12 (Scheme 3)and another from synthesis of halo carbonyl phenyl carbamates $\mathbf{1 5}$ (Scheme 4) from trifluoromethoxy aniline $\mathbf{1 3}$ via phenyl carbamates 14. By combining 12 and 15, we attain indoxacarb 7 (Scheme 5) ${ }^{17}$.<smiles>O=C(Cl)OCC1c2ccccc2-c2ccccc21</smiles>

8
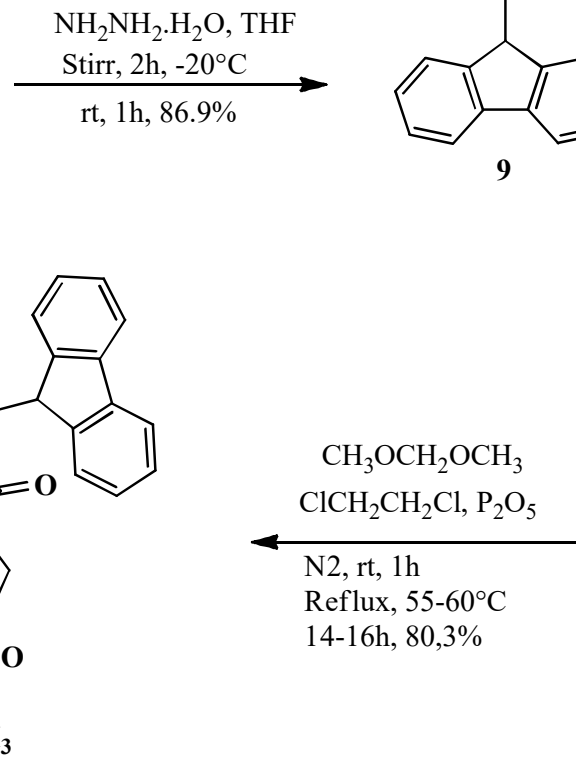<smiles>NNC(=O)OCC1c2ccccc2-c2ccccc21</smiles><smiles>COC(=O)[C@]1(O)Cc2cc(Cl)ccc2C1=O</smiles><smiles>COC(=O)[C@]1(O)Cc2cc(Cl)ccc2/C1=N\NC(=O)OCC1c2ccccc2-c2ccccc21</smiles>

11

12

Scheme 3. Synthesis of 1,3,4-oxadiazine dicarboxylate from 9-fluorenylmethyl chloroformate

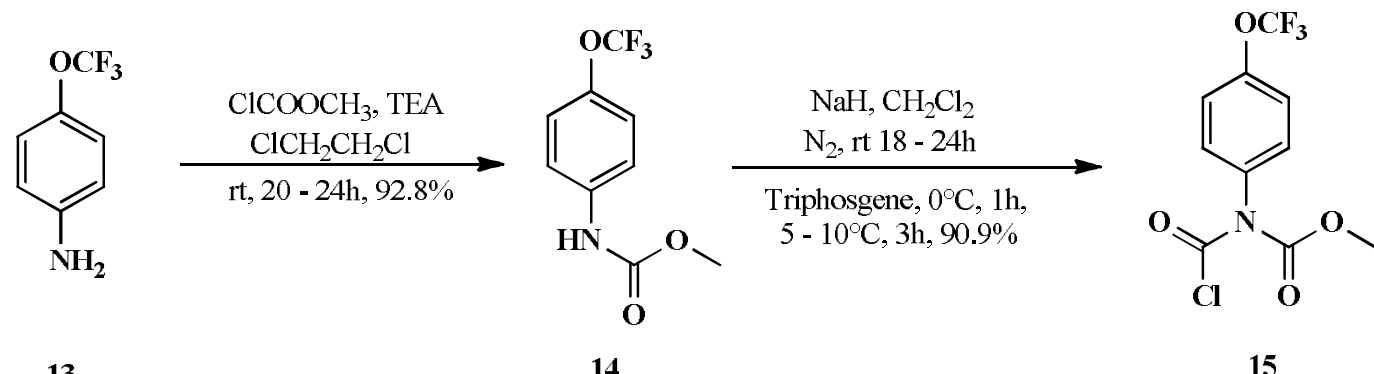

13

Scheme 4. Synthesis of halo carbonyl phenyl carbamates from trifluoromethoxy aniline 
<smiles>COC(=O)[C@@]1(C(=O)Cl)OCN(C(=O)OCC2c3ccccc3-c3ccccc32)N=C2c3ccc(Cl)cc3C[C@@]21C(=O)OC</smiles>

Scheme 5. Synthesis of Indoxacarb from 1,3,4-oxadiazine dicarboxylate with halo carbonyl phenyl carbamates.

Synthesis of oxadiazine scaffolds

\section{1,2,4-oxadiazine scaffolds}

Synthesis from 1-arylaziridine oximes 16 which is obtained from benzonitrile oxides with ethyleneimine or propylenimine in an ether, reacting with concentrated $\mathrm{HCl}$ by an acid catalyzed mechanism to get intermediate $\mathbf{1 7}$ then further basified with $\mathrm{NaOH}$ to get the desired scaffold of 1,2,4-oxadiazine $\mathbf{1 8}$ (Scheme 6) ${ }^{18}$.

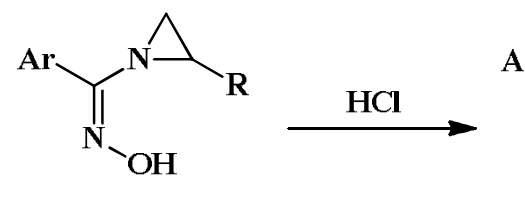

16<smiles>[R]C([Y19])CNC([Al])=NO</smiles>

17<smiles>[R]C1CNC([Al]CC#C)=NO1</smiles>

18

Scaffolds 16-18:

\begin{tabular}{|c|c|c|c|c|}
\hline S.No & & ubstituents & & \\
\hline & $\overline{\mathrm{R}}$ & $\mathrm{Ar}$ & $\mathrm{X}$ & \\
\hline 1 & $\mathrm{H}$ & $4-\mathrm{Cl}-\mathrm{C}_{6} \mathrm{H}_{4}$ & Cl & Scaffold 17 \\
\hline 2 & $\mathrm{H}$ & $4-\mathrm{Cl}-\mathrm{C}_{6} \mathrm{H}_{4}$ & $\mathrm{Br}$ & Scall toid it \\
\hline 3 & $\mathrm{H}$ & $4-\mathrm{Cl}-\mathrm{C}_{6} \mathrm{H}_{4}$ & - & 7 \\
\hline 4 & $\mathrm{H}$ & $\mathrm{C}_{6} \mathrm{H}_{5}$ & - & \\
\hline 5 & $\mathbf{H}$ & $3,4\left(\mathrm{Cl}_{2} \mathrm{C}_{6} \mathrm{H}_{3}\right.$ & - & Scaffold 16 and 18 \\
\hline 6 & $\mathrm{CH}_{3}$ & $\mathrm{C}_{6} \mathrm{H}_{5}$ & - & \\
\hline 7 & $\mathrm{H}$ & $\mathrm{NO}_{2} \mathrm{C}_{6} \mathrm{H}_{4}$ & - & \\
\hline
\end{tabular}

a No data exists on yield and time

Scheme 6. Synthesis of 1,2,4-oxadiazines from 1-arylaziridine oximes

Heating the reaction mixture of nitrone 19 with 1aroylaziridine $\mathbf{2 0}$ in toluene and acetic acid to form the corresponding 4-acyltetrahydro- $2 H-1,2,4-$ oxadiazines $\mathbf{2 1}$ with moderate to good yield (Scheme 7) ${ }^{19}$.

Enantiomeric form of amino alcohol 23 from 1,2,3-trifluoro-5-vinylbenzene $\mathbf{2 2}$ which on reacting with carboxylic acid derivative 23A to form an amide 24further undergoes cyclization to form lactam ring $\mathbf{2 5}$ then series of conversions to hydroxylamine $\mathbf{2 6}$ and cyclization leads to form 1,2,4-oxadiazine enantiomer
27 (Scheme 8) (Yield 90\%). The obtained scaffold was subjected to $\gamma$-secretase modulators in-vivo in which the scaffold shows a potent activity for Alzheimer's disease. The compounds of monosubstituted 1,2,4-oxadiazines $\mathbf{2 8}$ at $\mathrm{C}-3$ position with a trifluorophenyl group shows good activity along with good selectivity with $45 \%$ inhibition $\mathrm{A} \beta_{42}$ in rat cerebrospinal fluid, the compounds of monosubstituted 1,2,4-oxadiazines scaffolds 29 at C-4 Position with the same trifluorophenyl group and substituted chloro, fluoro derivatives to aryl groups shows potent along with good binding affinity ${ }^{20-21}$. 
<smiles>[R]C=[N+]([R7])[O-]</smiles>

Scaffold 19-21 :

\begin{tabular}{|c|c|c|c|}
\hline \multirow[t]{2}{*}{ S.No } & \multicolumn{3}{|c|}{ Substituents } \\
\hline & $\mathbf{R}_{\mathbf{1}}$ & $\mathbf{R}_{\mathbf{2}}$ & $\mathbf{R}_{\mathbf{3}}$ \\
\hline 1 & $\mathrm{C}_{6} \mathrm{H}_{5}$ & $\mathrm{C}_{6} \mathrm{H}_{5}$ & $4-\mathrm{NO}_{2}-\mathrm{C}_{6} \mathrm{H}_{4}$ \\
\hline 2 & $4-\mathrm{CH}_{3}-\mathrm{C}_{6} \mathrm{H}_{4}$ & $\mathrm{C}_{6} \mathrm{H}_{5}$ & $4 \mathrm{NO}_{2}-\mathrm{C}_{6} \mathrm{H}_{4}$ \\
\hline 3 & $4-\mathrm{CH}_{3}-\mathrm{C}_{6} \mathrm{H}_{4}$ & $\mathrm{C}_{6} \mathrm{H}_{5}$ & $3,5-\left(\mathrm{NO}_{2}\right)_{2}-\mathrm{C}_{6} \mathrm{H}_{3}$ \\
\hline 4 & $\mathbf{C H}_{3}$ & $\mathrm{C}_{6} \mathrm{H}_{5}$ & $3,5-\left(\mathrm{NO}_{2}\right)_{2}-\mathrm{C}_{6} \mathrm{H}_{3}$ \\
\hline 5 & $\mathrm{C}_{6} \mathrm{H}_{11}$ & $\mathrm{CH}_{3}$ & $3,5-\left(\mathrm{NO}_{2}\right)_{2}-\mathrm{C}_{6} \mathrm{H}_{3}$ \\
\hline 6 & $\mathrm{C}\left(\mathrm{CH}_{3}\right)_{3}$ & $\mathrm{C}_{6} \mathrm{H}_{5}$ & 4- $\mathrm{NO}_{2}-\mathrm{C}_{6} \mathrm{H}_{4}$ \\
\hline 7 & $4 \mathrm{CH}_{3}-\mathrm{C}_{6} \mathrm{H}_{4}$ & $\mathrm{C}_{6} \mathrm{H}_{5}$ & $3,4-(\mathrm{Cl})_{2}-\mathrm{C}_{6} \mathrm{H}_{3}$ \\
\hline 8 & $4-\mathrm{CH}_{3}-\mathrm{C}_{6} \mathrm{H}_{4}$ & $4-\mathrm{ClC}_{6} \mathrm{H}_{5}$ & $3,5-\left(\mathrm{NO}_{2}\right)_{2}-\mathrm{C}_{6} \mathrm{H}_{3}$ \\
\hline 9 & $4-\mathrm{C}_{2} \mathrm{H}_{5}-\mathrm{C}_{6} \mathrm{H}_{4}$ & $\mathrm{C}_{6} \mathrm{H}_{5}$ & $3,5-\left(\mathrm{NO}_{2}\right)_{2}-\mathrm{C}_{6} \mathrm{H}_{3}$ \\
\hline 10 & $\mathbf{C H}_{3}$ & $\mathrm{C}_{6} \mathrm{H}_{5}$ & $4-\mathrm{NO}_{2}-\mathrm{C}_{6} \mathrm{H}_{4}$ \\
\hline
\end{tabular}<smiles>C=Cc1cc(F)c(I)c(I)c1</smiles>

22<smiles>COc1cc(/C=C2\CCCN([C@H](CO)c3cc(F)c(F)c(F)c3)C2=O)ccc1-n1cnc(C)c1</smiles>

25

i) $\mathrm{N}$-Hydroxyphthalimide, ii) $\mathrm{NH}_{2} \mathrm{NH}_{2}, \mathrm{EtOH}$ $\mathrm{PPh}_{3}$, DIAD, THF $\mathrm{rt}$, overnight $-10^{\circ} \mathrm{C}, 30 \mathrm{~min}$

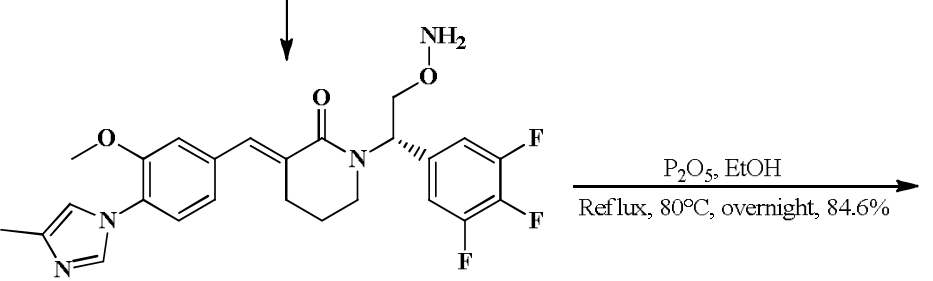

26<smiles>COc1cc(/C=C(\CCCCl)C(=O)O)ccc1-n1cnc(C)c1</smiles><smiles>COc1cc(/C=C(\CCCCl)C(=O)N[C@@H](CO)c2cc(F)c(F)c(F)c2)ccc1-n1cnc(C)c1</smiles>

24

Scheme 8. Synthesis of 1,2,4-oxadiazine scaffold from 3,4,5-trifluoro substituted styrene 


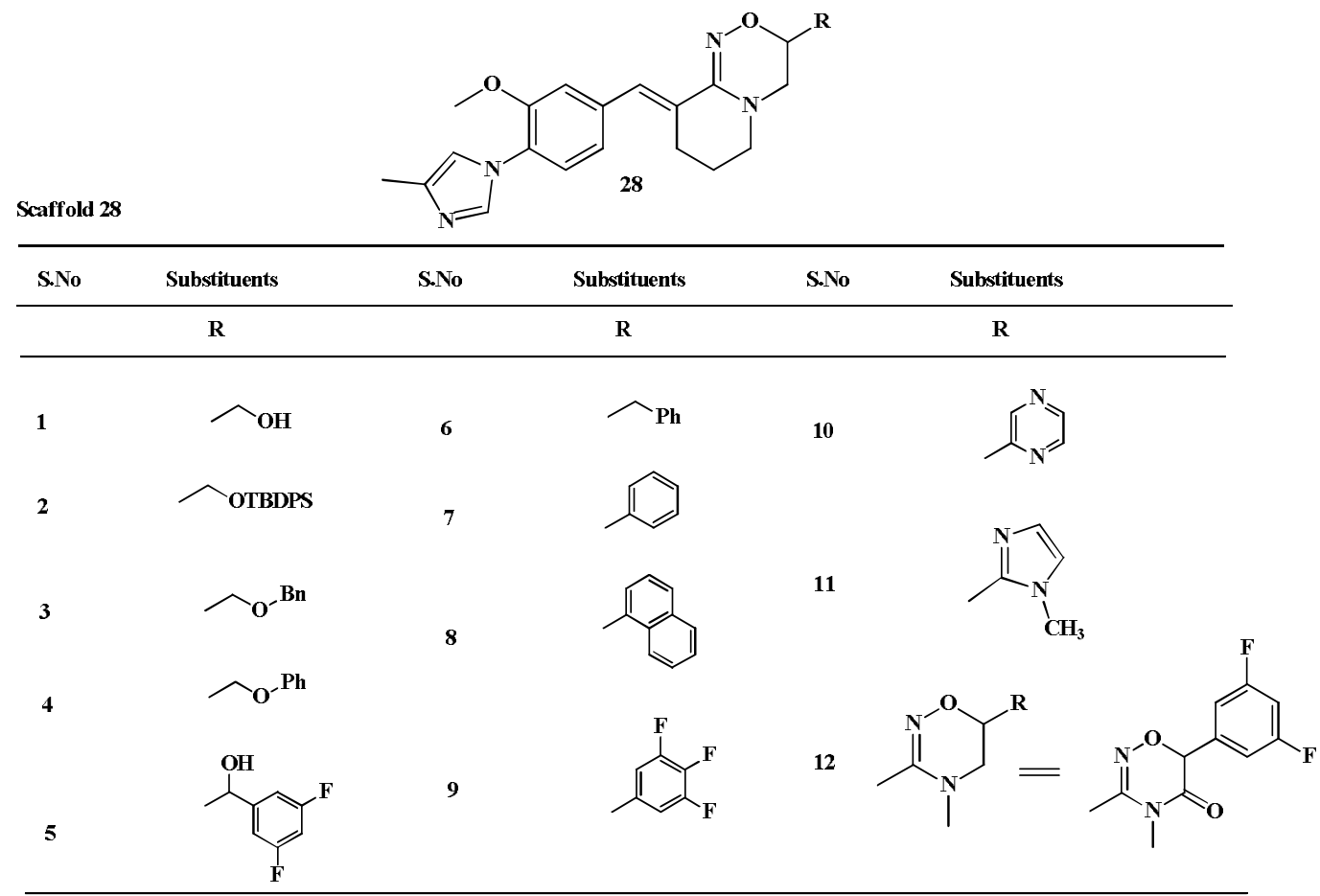

AR of monosubstituted 1,2,4-oxadiazines Scaffolds at the C-3 position

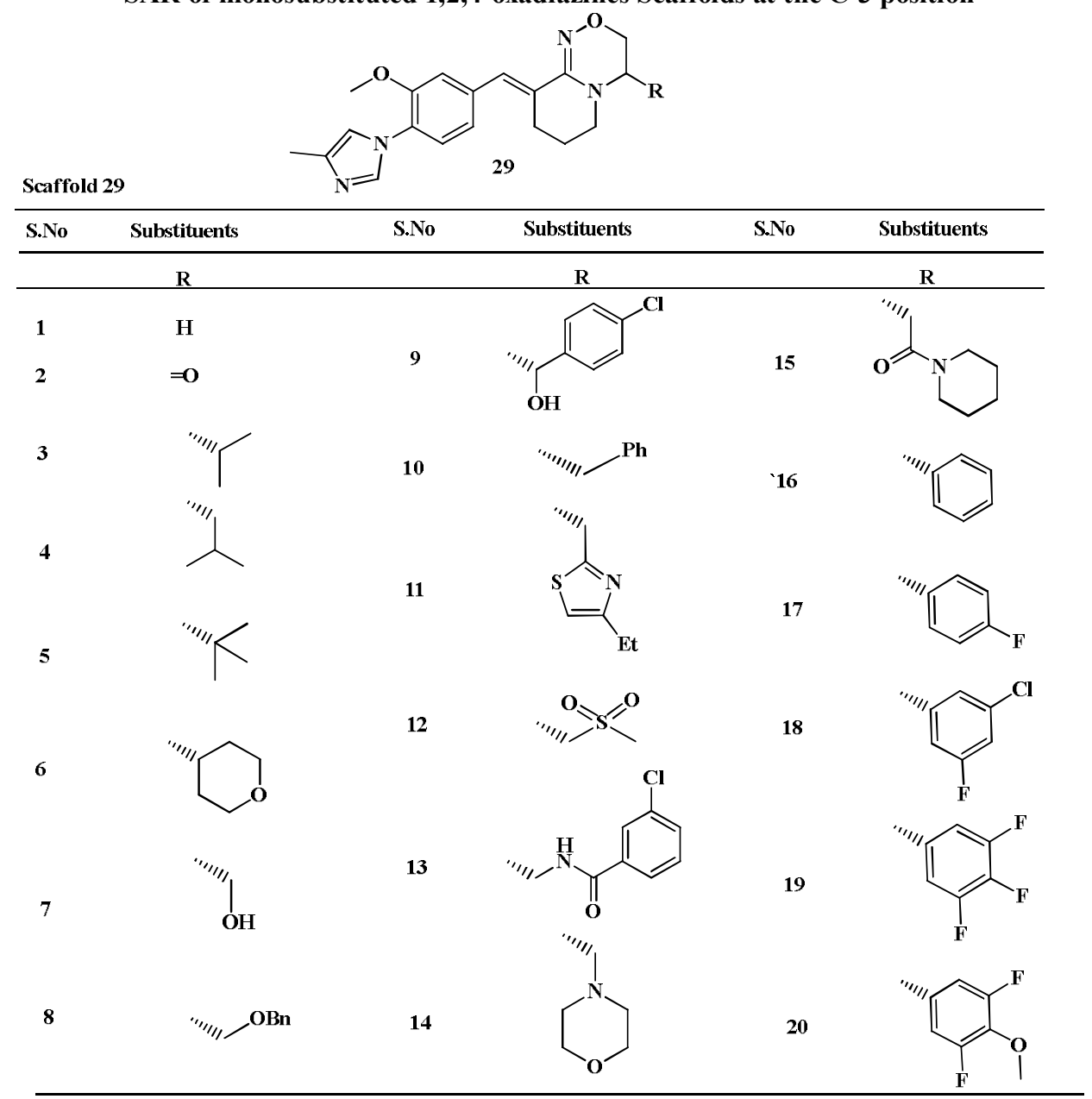

SAR of monosubstituted 1,2,4-oxadiazines Scaffolds at the C-4 position 
Aziridines $\mathbf{3 0}$ with nitrones $\mathbf{3 1}$ by annulation in the presence of a Lewis acid catalyst $\mathrm{InCl}_{3}$ to get the scaffolds of 1,2,4-oxadiazines 32 (Scheme 9) ${ }^{22}$.

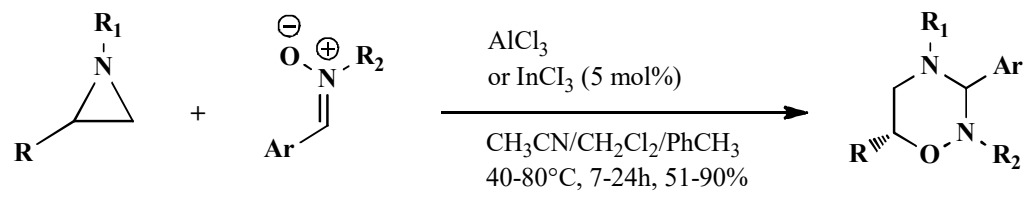

30

32

Scaffold 30-32:

\begin{tabular}{lllll}
\hline S. No & \multicolumn{4}{c}{ Substituents } \\
\hline & R & $\mathrm{R}_{1}$ & $\mathrm{R}_{2}$ & $\mathrm{Ar}$ \\
\hline 1 & $\mathrm{Bn}$ & $-\mathrm{CH}_{3}$ & $\mathrm{Ph}$ \\
\hline & & & & \\
\hline
\end{tabular}

Scheme 9. Synthesis of 1,2,4-oxadiazines from aziridines and nitrones

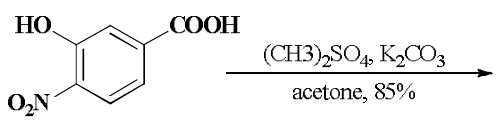

33<smiles>COc1cccc(C(=O)OCc2ccc([N+](=O)[O-])c(OC)c2)c1</smiles>

34<smiles>COc1cc(C(C)=O)ccc1N</smiles>

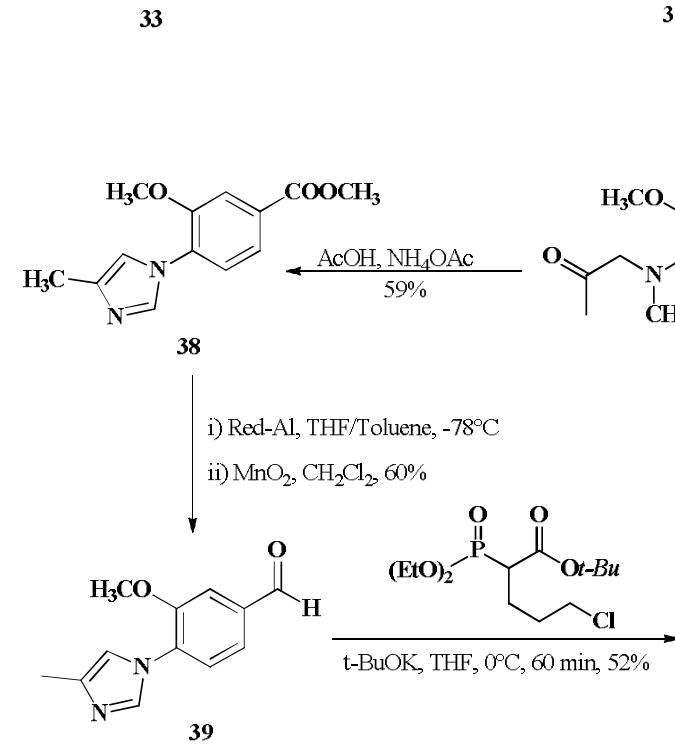

39<smiles>COC(=O)C(=Cc1ccc(-n2cnc(C)c2)c(OC)c1)CCCCl</smiles>

40<smiles></smiles>

Scheme 10. Synthesis of $\alpha, \beta$-Unsaturated carboxylic acid from 3-Hydroxy-4-nitrobenzoic acid 
Application of retrosynthetic strategy in two steps to synthesize the 1,2,4-oxadiazines scaffold one from 3-Hydroxy-4-nitrobenzoic acid 33 undergoes methylation with dimethyl sulfate to get $\mathbf{3 4}$ further undergoes a series of reaction like reduction to form amino group $\mathbf{3 5}$ followed by formylation to get $\mathbf{3 6}$ dehalogenations by halo acetone to form 37 undergoes. The cyclization forms imidazole ring 38 reduced to aldehydes 39 with tert-Butyl ester to form 40 followed to form acid derivative 23A (Scheme 10). Another from 5-bromo 1,2,3- trifluorobenzene $\mathbf{4 1}$ to form 2-oxo-2-(3,4,5trifluorophenyl)acetic acid $\mathbf{4 2}$ which under reductive amination form amino acid $\mathbf{4 3}$, which further reduced to amino alcohol 44 (Scheme 11).Combination of both $23 \mathrm{~A}$ and $\mathbf{4 4}$ forms an amide 45 cyclization takes place to form saturated pyridine 46. Further it reacts with $N$-hydroxypthalimide and hydroxylamine to form hydroxylamine $\mathbf{4 8}$ derivatives via $\mathbf{4 7}$ it rearranges to form 1,3,4-oxadiazine scaffold 49 (Scheme 12) ${ }^{23}$

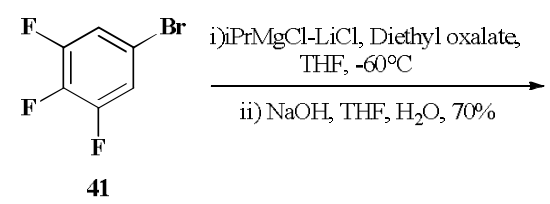

41<smiles>O=C(O)C(=O)c1cc(F)c(F)c(I)c1</smiles>

4

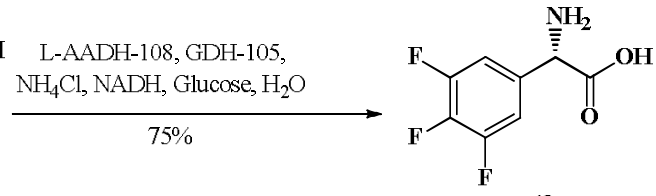<smiles>O=C(O)C(O)c1ccccc1</smiles><smiles>OC[C@@H](O)c1cc(F)c(F)c(F)c1</smiles>

Scheme 11. Synthesis of amino alcohol from 5-bromo-1,2,3-trifluorobenzene

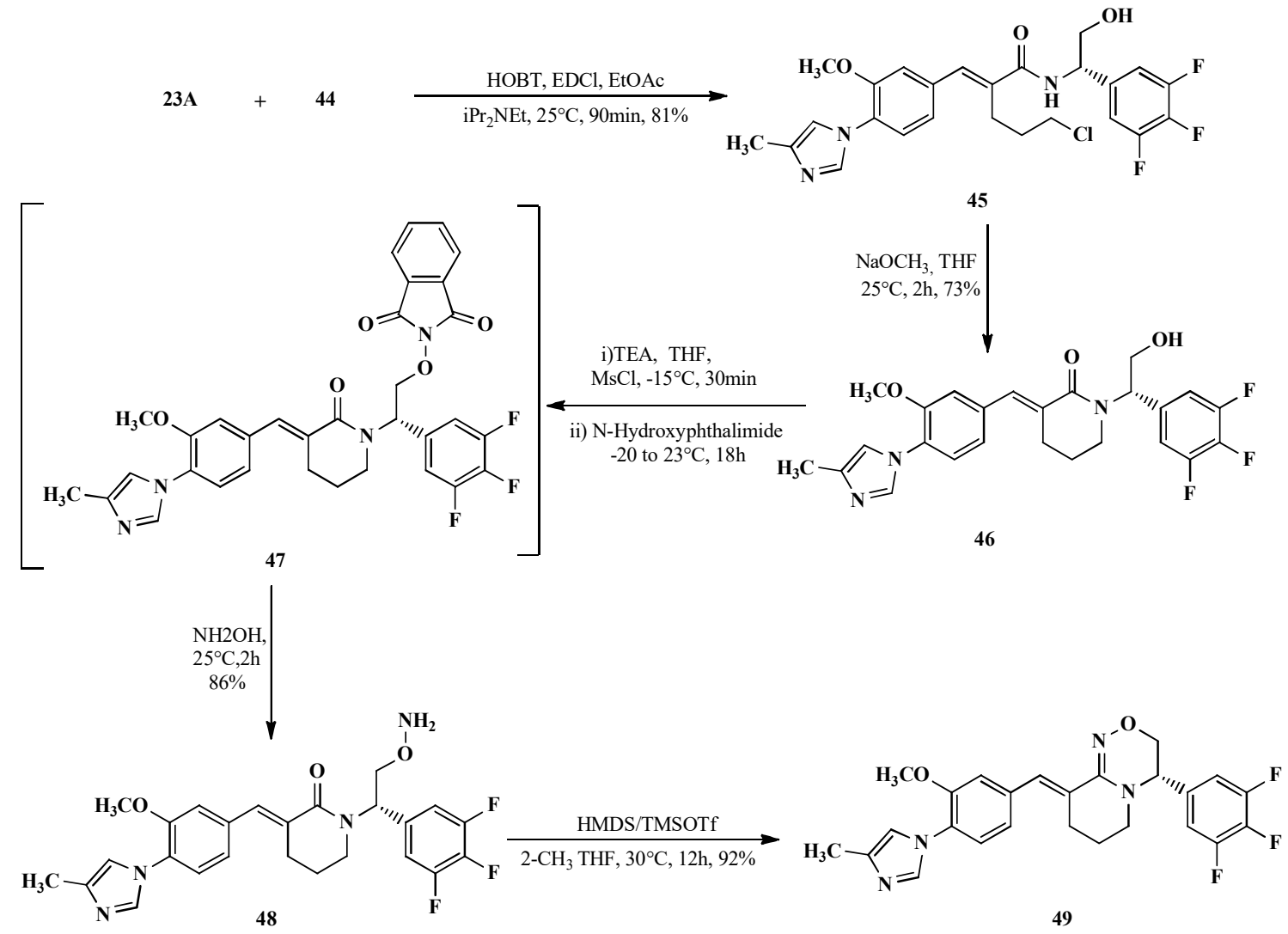

Scheme 12. Synthesis of 1,2,4-oxadiazines scaffold from both $\alpha, \beta$-unsaturated carboxylic acid with amino alcohols 
Development of 1,2,4-oxadiazines from [3+3] cycloaddition of Ketoximes $\mathbf{5 0}$ with $\mathrm{N}$-tosylaziridines $\mathbf{5 1}$ in annelated carbocycles formed by extending the three-membered cycle into oxadiazines 52 (Scheme 13) ${ }^{24}$.

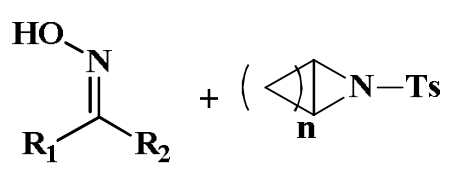

50

51

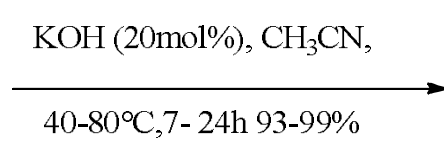

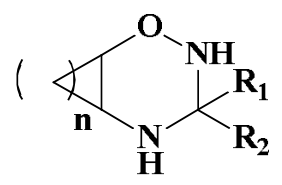

52

$\mathrm{n}=1,3,4 ; \mathrm{R} 1=\mathrm{Ph}, 2$-thienyl, 2-naphthyl; $\mathrm{R}_{2}=\mathrm{Me}, \mathrm{Et}$

Scheme 13. Synthesis of 1,2,4-oxadiazines scaffolds by [3+3] cycloaddition of Ketoximes with $N$-tosylaziridines

A base-controlled [3+3] cycloadditions of isoquinoline $N$-oxides $\mathbf{5 3}$ treated with $\alpha$-halohydroxamates 54 in the presence of sodium carbonate in acetonitrile via azaoxyallyl cation<smiles>[R1]c1cccc2c[n+]([O-])c([R2])cc12</smiles>

53

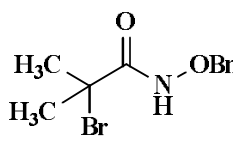

54 to afford $1,11 b$-dihydro[1,2,4] oxadiazine[3,2-a]-isoquinolin-2(3H)-ones 55 with moderate to good yield (Scheme 14) ${ }^{25}$.

Scheme 14 Synthesis of 1,2,4-oxadiazines scaffolds by [3+3] cycloaddition of isoquinoline $N$-oxides with $\alpha$-halohydroxamates

Cobalt (II) catalyzed oxidative coupling of 2-benzamidopyridine 1-oxide $\mathbf{5 6}$ with phenylacetylene $\mathbf{5 7}$ by alkynylation/Annulation to get the (Z)-2-(1-benzylidene-3-oxoisoindolin-2-yl)-pyridine- 1-oxide $\mathbf{5 8}$ which undergoes annulation with Ceric (IV) ammonium nitrate to get the 1,2,4-oxadiazine $\mathbf{5 9}$ (Scheme 15) ${ }^{26}$.

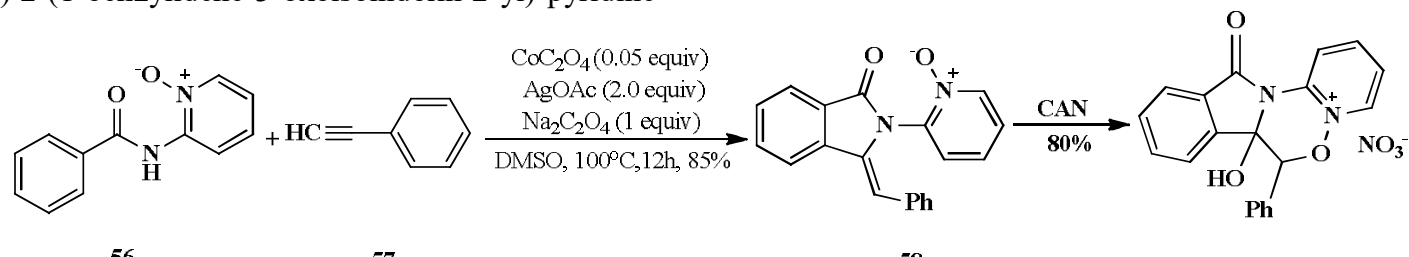

Scheme 15 Synthesis of 1,2,4-oxadiazines scaffolds by oxidative coupling of 2-benzamidopyridine 1-oxide with phenylacetylene

Methyl 2-(1-acetyl-1, 2-dihydropyridin-2-yl) acetate 60 with either nitroso/hydroxyl amino group $\mathbf{6 1}$ by [4+2] cycloaddition reaction to attain a high degree of regioselectivity to prepare 1,2,4-oxadiazine $\mathbf{6 2}$ and its isomer of 1,2,5-oxadiazine $\mathbf{6 3}$ (Scheme 16) ${ }^{27}$.<smiles>[R10]N=O</smiles>

60 i) $\mathrm{CH}_{2} \mathrm{Cl}_{2}, \mathrm{rt}, \mathrm{lh}$ (or) ii) $\mathrm{NaIO}_{4}, \mathrm{CH}_{3} \mathrm{OH}, \mathrm{H}_{2} \mathrm{O}, 0^{\circ} \mathrm{C}, 3 \mathrm{~h}$ (or)

iii) $\mathrm{NaIO}_{4}, \mathrm{CH}_{3} \mathrm{OH}, \mathrm{H}_{2} \mathrm{O}, 0^{\circ} \mathrm{C}, 3 \mathrm{~h}$ $23-70 \%$

$\mathrm{R}=$ Phi, BnCOii， Bociii<smiles>[R]N1OC2C=CC1N([Z])C2CC(C)=O</smiles>

62
63

Scheme 16. Synthesis of 1,2,4-oxadiazines scaffolds by [4+2] cycloaddition of either nitroso/hydroxylamino group with dihydropyridinyl acetate 
Irreversible condensation reacting aliphatic, aromatic, unsaturated aldehydes and isatins $\mathbf{6 5}$ with $\alpha$-aminooxyacetohydrazides 64 in acetonitrile and acetate buffer to attain 1,2,4-oxadiazinan-5-one heterocycles $\mathbf{6 6}$ moderate to good yields (Scheme 17) ${ }^{28}$.

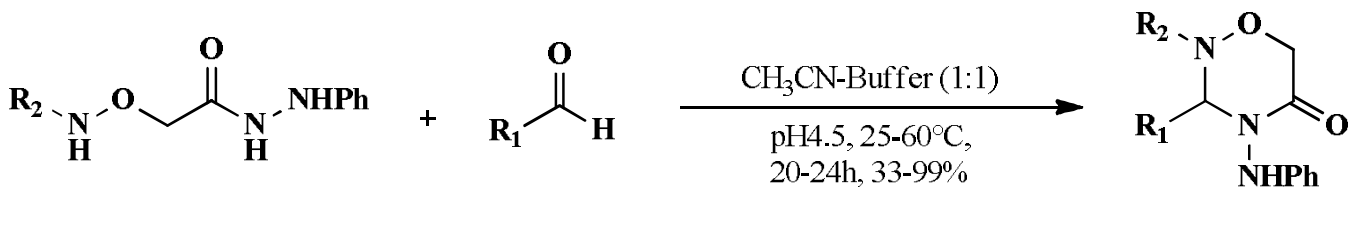

64

65

66

R1=Het, Ar, Alkyl, Alkenyl; R2= Bn, i-Pr, $\mathrm{Ph}(\mathrm{CH} 2)_{3}, \mathrm{Allyl}, \mathrm{Cy}$

Scheme 17. Synthesis of 1,2,4-oxadiazinan-5-one from $\alpha$-aminooxyacetohydrazides

Cyclocondensation reaction with a substituted 2-(aminooxy) ethanamine $\mathbf{6 7}$ with an orthoesters imino ethers 68 in the presence of acetic acid to affords 1,2,4-oxadiazines 69 with a low to moderate yield (Scheme 18) ${ }^{29}$.

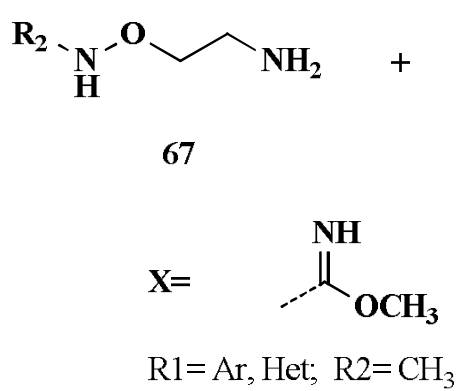

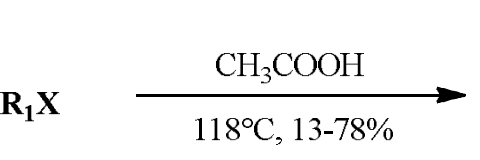

68<smiles>[R]C1=NCCON1[R2]</smiles>

69

Scheme 18. Synthesis of 1,2,4-oxadiazines from 2-(aminooxy) ethanamine

[3+3] cycloaddition reaction of in the presence of base accessed the novel 1,2,4$\alpha$-halohydroxamate 70 with hydroximoyl chloride $71 \quad$ oxadiazinan-5-ones 72 (Scheme 19) ${ }^{30}$.<smiles>[R]C([R])([R])C(=O)NOCCO</smiles>

70<smiles>[R]/C(Cl)=N/O</smiles>

71

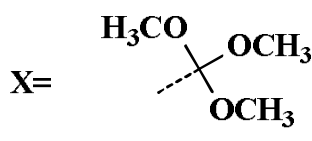

$\mathrm{R} 1=$ Het, R2 $=\mathrm{H}$

\section{$\mathrm{R}=-\mathrm{C}_{6} \mathrm{H}_{5}, 2 \mathrm{ClC}_{6} \mathrm{H}_{4}, 2 \mathrm{OCH}_{3} \mathrm{C}_{6} \mathrm{H}_{4}, 3 \mathrm{ClC}_{6} \mathrm{H}_{4}, 4-\mathrm{ClC}_{6} \mathrm{H}_{4}, 4-\mathrm{CH}_{3} \mathrm{C}_{6} \mathrm{H}_{4}, 4-\mathrm{NO}_{2} \mathrm{C}_{6} \mathrm{H}_{4}, 4-\mathrm{FC}_{6} \mathrm{H}_{4}, 2 \mathrm{Cl}, 4 \mathrm{ClC}_{6} \mathrm{H}_{3}$, 2-Furyl, 2-Napthyl, n-Propyl} $\mathrm{R} 1=-\mathrm{CH}_{3},-\mathrm{C}_{2} \mathrm{H}_{5},-\mathrm{C}_{6} \mathrm{H}_{5}, \mathrm{R} 2=-\mathrm{H},-\mathrm{CH}_{3},-\mathrm{C}_{2} \mathrm{H}_{5} \quad \mathrm{X}=\mathrm{Br}, \mathrm{Cl}$

Scheme 19. Synthesis of 1,2,4-oxadiazinan-5-ones by [3+3] cycloaddition reaction $\alpha$-halohydroxamate with hydroximoyl chloride

\section{1,2,5-oxadiazine scaffolds}

Aza lactone $\mathbf{7 3}$ when reacting with $N$-Phenylhydroxylamine by removal of the water molecule to form the 4-arylmethylene-2,6-diphenyl-
$2 H$-1,2,5-oxadiazin-3(4H)-ones $\mathbf{7 4}$ which on reacting with different amines or benzene thiols further obtained 2H-1,2,5-oxadiazin-3(4H)-ones 75 (Scheme 20) ${ }^{31}$. 
<smiles>[R1]C=C1N=C(c2ccccc2)OC1=O</smiles>

73<smiles>[R3]C=C1N=C(c2ccccc2)ON(c2ccccc2)C1=O</smiles>

74

\section{Scaffold 73-75:}

\begin{tabular}{|c|c|c|c|c|c|}
\hline \multirow[t]{2}{*}{ S.No } & \multicolumn{2}{|l|}{ Substituents } & \multirow[t]{2}{*}{ S.No } & \multicolumn{2}{|c|}{ Substituents } \\
\hline & $\mathbf{R}_{\mathbf{1}}$ & $\mathrm{XR}_{2}$ & & $\mathbf{R}_{\mathbf{1}}$ & $\mathrm{XR}_{\mathbf{2}}$ \\
\hline 1 & Ph & NHBn & 6 & $\mathbf{P h}$ & S-3-Tol \\
\hline 2 & 4-To; & NHBn & 7 & $4-\mathrm{MeOC}_{6} \mathrm{H}_{4}$ & SPh \\
\hline 3 & $4-\mathrm{MeOC}_{6} \mathrm{H}_{4}$ & NHBn & 8 & $4-\mathrm{MeOC}_{6} \mathrm{H}_{4}$ & S-2-Tol \\
\hline 4 & Ph & SPh & 9 & $4-\mathrm{MeOC}_{6} \mathrm{H}_{4}$ & S-3-Tol \\
\hline 5 & Ph & S-2-Tol & & & \\
\hline
\end{tabular}

Scheme 20. Synthesis of 1,2,5-oxadiazines from azalactones reacting with $N$-Phenylhydroxylamine

Substituted 1,2,5-oxadiazin-3,6-dione 79 from 2-(1H-benzo[ $d][1,2,3]$ triazole-1-carboxamido $)$ (Scheme 21) from $N$-Phenyl hydroxyl amine reacting on $\quad 2-(1 H$-benzo $[d][1,2,3]$ triazole-1-carboxamido $)$ carboxylic acid chloride 77 which was obtained carboxylic acid 76 to get $N$-(1-(hydroxyl-(phenyl)amino)-1-oxo-2-yl)-1H-benzo[ $d][1,2,3]$-triazole-1carboxamide $\mathbf{7 8}$ with low to moderate yields ${ }^{32}$.<smiles>[R]C(NC(=O)n1nnc2ccccc21)C(=O)O</smiles>

76

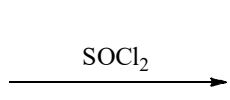

$$
\text { (n) }
$$

\begin{tabular}{|c|c|}
\hline \multicolumn{2}{|c|}{ Scaffold 76-79 } \\
\hline S.No & Substituents \\
\hline & $\mathbf{R}$ \\
\hline 1 & $\mathbf{H}$ \\
\hline 2 & $\mathrm{CH}_{3}$ \\
\hline 3 & Bn \\
\hline
\end{tabular}

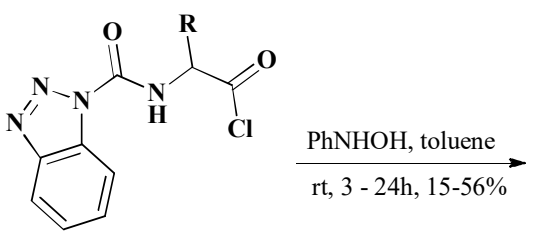

77<smiles>[R]C(NC(=O)n1nnc2ccccc21)C(=O)N(O)c1ccccc1</smiles>

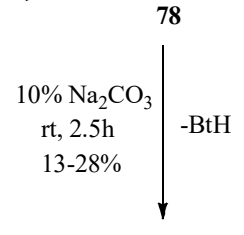<smiles>[R]C1NC(=O)ON(c2ccccc2)C1=O</smiles>

79

Scheme 21. Synthesis of 1,2,5-oxadiazines from benzotriazole-1-carboxamido carboxylic acid

4,6-dichloro-5-nitrobenzo[c][ 1,2,5]oxadiazole1-oxide 80 with propan-2-ol in presence of sulphuric acid to obtain 4,6-dichloro-2,2-dimethyl-5-nitro- $2 \mathrm{H}$ benzo[ $d]$ imidazole 1,3-dioxide 81 which on heating in presence of light affords to give 6,8-dichloro-3,3dimethyl-7-nitro-3H-benzo[c] $[1,2,5]$ oxadiazine 4-oxide 82 which on further reaction with amine to undergo dehydrohalogenation reaction to obtain the scaffold of 82A (Scheme 22) which is reacted with secondary cyclic amines to get 8-substituted scaffolds with an good yield ${ }^{33}$. 


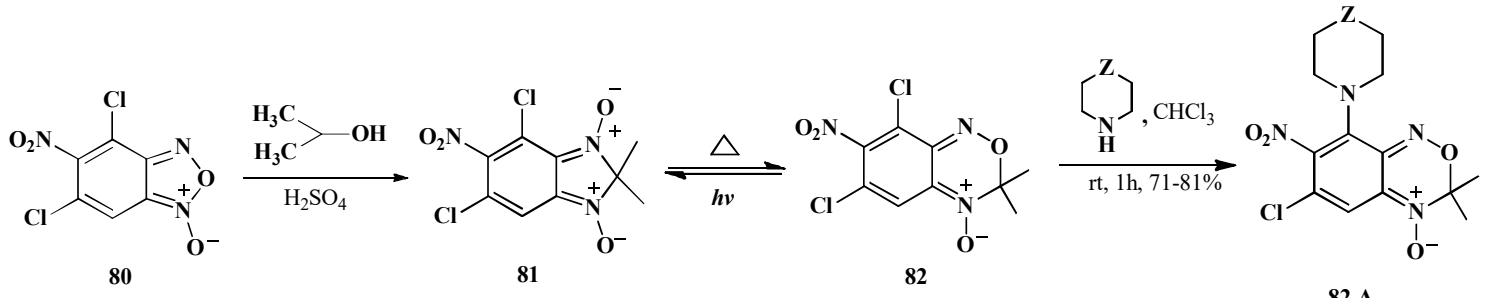

80

$\mathrm{Z}=\mathrm{O},-\mathrm{CH}_{2}, \mathrm{~N}-\mathrm{CH}_{3} \cdot \mathrm{HCl}$

82 A

Scheme 22. Synthesis of 1,2,5-oxadiazines from substituted benzooxadiazole-1-oxide

\section{1,3,4-oxadiazine scaffolds}

1,3,4-oxadiazines from 2-Cyanoaceto hydrazide 83 with 2-bromoketones 84 to form 2-bromohydrazone moieties 85 which undergoes cyclization with sodium ethoxide in ethanol to get the desired moiety 86 (Scheme 23) which was evaluated for antimicrobial, antifungal activities. It has shown good activity against Bacillus cereus, less active against Bacillus Subtilis, C.albicans, no active towards E.coli., and al antitumor activity on different human cell lines like MCF-7(adenocarcinoma), NCIH460(non-small cell lung cancer) and SF-268(CNS cancer) out of which nitro compound in ortho position showed the highest inhibitory effect ${ }^{34-35}$.

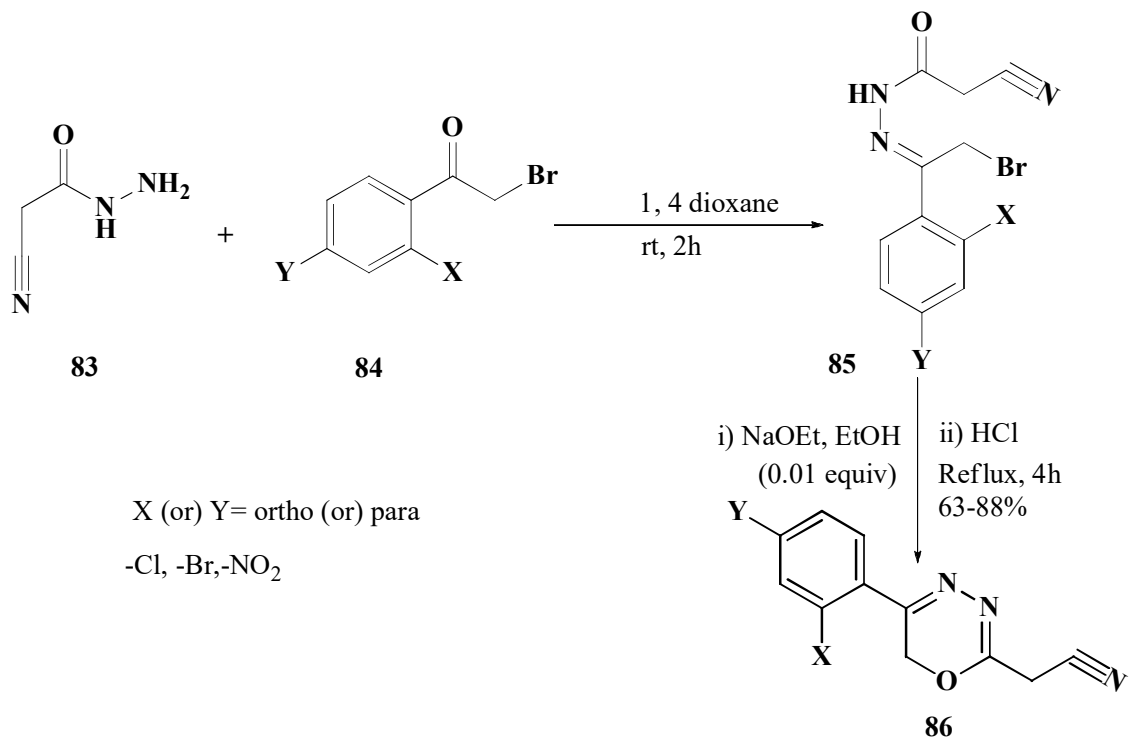

Scheme 23. Synthesis of 1, 3, 4-oxadiazines scaffolds from hydrazide-hydrazones

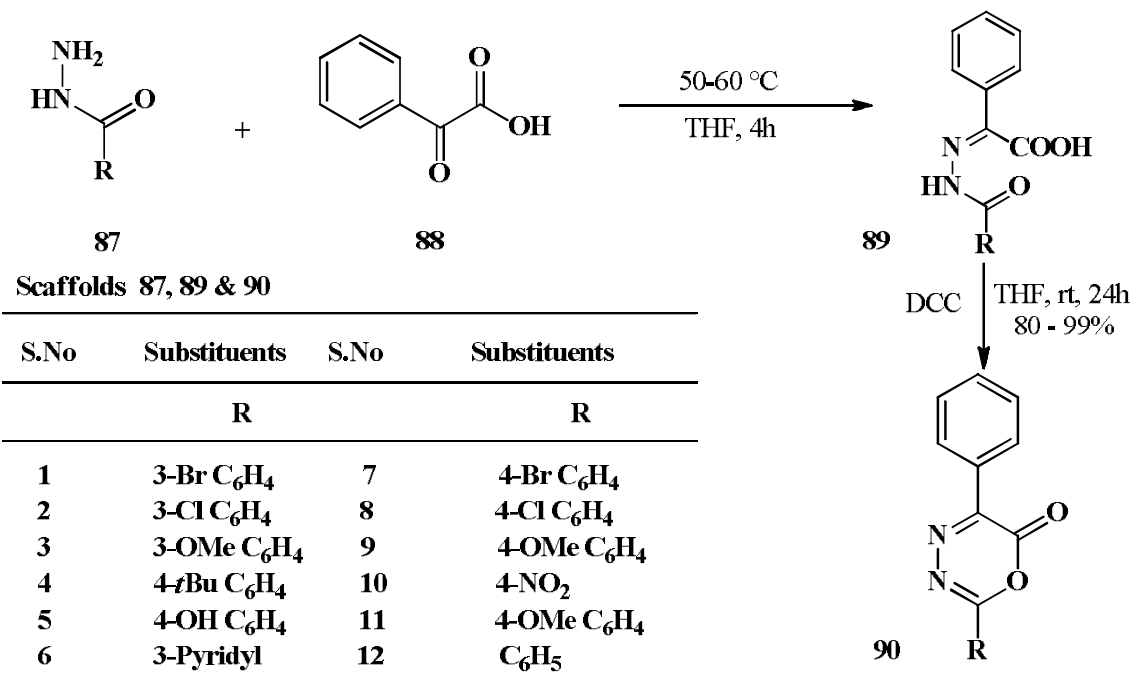

Scheme 24. Synthesis of 1,3,4-oxadiazines from $N$-acyl hydrazones 
Synthesis and characterization of different 2,5disubstituted 1,3,4-oxadiazin-6-ones 90 (Scheme 24) from variously substituted aroyl hydrazones $\mathbf{8 7}$ and phenylglyoxylic acid $\mathbf{8 8}$ by intermediate formation of $N$-acyl hydrazones 89 with a high yield ${ }^{36}$.

A chemical reaction involving a mixture of phenacyl chloride 91 with substituted benzhydrazides
92 in ethanol and piperidine to get hydrazides $\mathbf{9 3}$ which on cyclization with polyphosphoric acid in acetic acid to get the desired scaffolds of 2,6-diaryl1,3,4-oxadiazines 94 (Scheme 25) which have found that it is effective against gram-positive bacteria rather than gram-negative bacteria ${ }^{37}$.

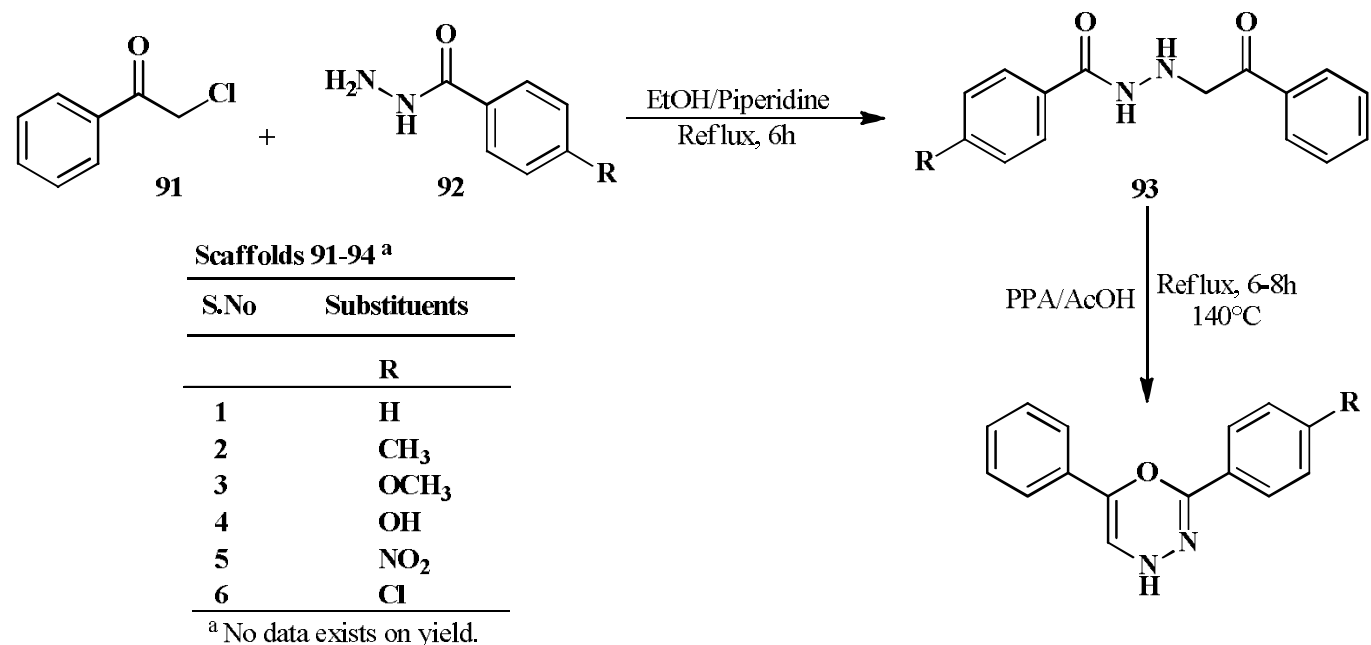

Scheme 25. Synthesis of 2,6 diaryl 1,3,4-oxadiazines from phenacyl chloride and substituted benzhydrazides.

Isatin derivatives 95 were reacted with 3,4-disubstituted acid hydrazide 96 in ethanol to form hydrazones 97 which is an intermediate molecule treated with a strong acid(conc. $\left.\mathrm{H}_{2} \mathrm{SO}_{4}\right)$ undergoes cyclization to form 1,3,4-oxadiazines $\mathbf{9 8}$ further reacted with aldehydes gives imines or Schiff's base 99 (Scheme 26). The final scaffolds have screened for antimicrobial and antifungal activities in which the chloro derivatives have shown the minimal zone of inhibition when compared to that of standards ${ }^{38}$.<smiles>[R]c1ccc2c(c1)C(=O)C(=O)N2</smiles>

95<smiles>NNC(=O)c1ccc(O)c(N)c1</smiles>

96<smiles>[R]c1ccc2c(c1)/C(=N/NC(=O)c1ccc(O)c(N)c1)C(=O)N2</smiles>

97

$\mathbf{R}_{1}$<smiles></smiles><smiles>CCCCCCCCCC</smiles><smiles>[R]c1ccc2nc3oc(-c4ccc(O)c(N)c4)nnc-3c2c1</smiles>

$$
\begin{array}{ll}
\mathrm{R} 1=\mathrm{F}, \mathrm{Cl}, \mathrm{CH}_{3} & \mathrm{R} 2=\mathrm{H}, \mathrm{OH} \\
\mathrm{R} 3=\mathrm{H}, \mathrm{OH}, \mathrm{OCH}_{3} \mathrm{~N}_{\left(\mathrm{CH}_{3}\right)_{2}} & \mathrm{R} 4=\mathrm{HOCH}_{3}
\end{array}
$$

Scheme 26. Reaction of isatin derivatives with acid hydrazides to form 1,3,4-oxadiazino[5,6- $b]$ indole derivatives 
One pot synthesis by reacting substituted acetophenones $\mathbf{1 0 0}$ and acid hydrazides using [Hydroxy(tosyloxy)iodo]benzene (HTIB) which is a hypervalent iodine (III) reagent to form 2,5disubstituted 1,3,4-oxadiazine 101 (Scheme 27) ${ }^{39}$.<smiles>[14CH3]C([14CH3])=O</smiles>

100

\section{i) $\mathrm{Ph}(\mathrm{OH}) \mathrm{OTs}, \mathrm{CH}_{3} \mathrm{CN}$ reflux, 1-1.5h}<smiles>[Y11]C(=[V])NN</smiles><smiles></smiles>

101

Scheme 27. Synthesis of 2,5 disubstituted 1,3,4-oxadiazines from substituted acetophenones using HTIB.

Synthesis of hydrophobic long alkyl chains from a basic skeleton of carboxylic derivative $\mathbf{1 0 2}$ which is converted to hydrazides $\mathbf{1 0 3}$ by hydrazine hydrate, further condensed with nonan-5-one with a specific reducing agent $\mathrm{NABH}_{4}$ and on the other hand, it is condensed with acrylonitrile or $n$-butyl acrylate to get the desired moieties $\mathbf{1 0 4}$ and 105. The obtained compounds undergo cyclization with chloroacetyl chloride get the 1,3,4-oxadiazine scaffolds $\mathbf{1 0 6}$
(Scheme 28). The obtained scaffolds are evaluated for inhibition of monoamine oxidase, chitin synthesis and on tumor cell lines (Human lung cancer cell A-549 and Prostate cancer cell PC-3). Trimethoxy scaffolds shown to be most potential growth inhibition in monoamine oxidase and antitumor activities but for chitin synthesis inhibition, the moieties with ethoxy and $n$-butyl acrylate are potential ${ }^{40}$.

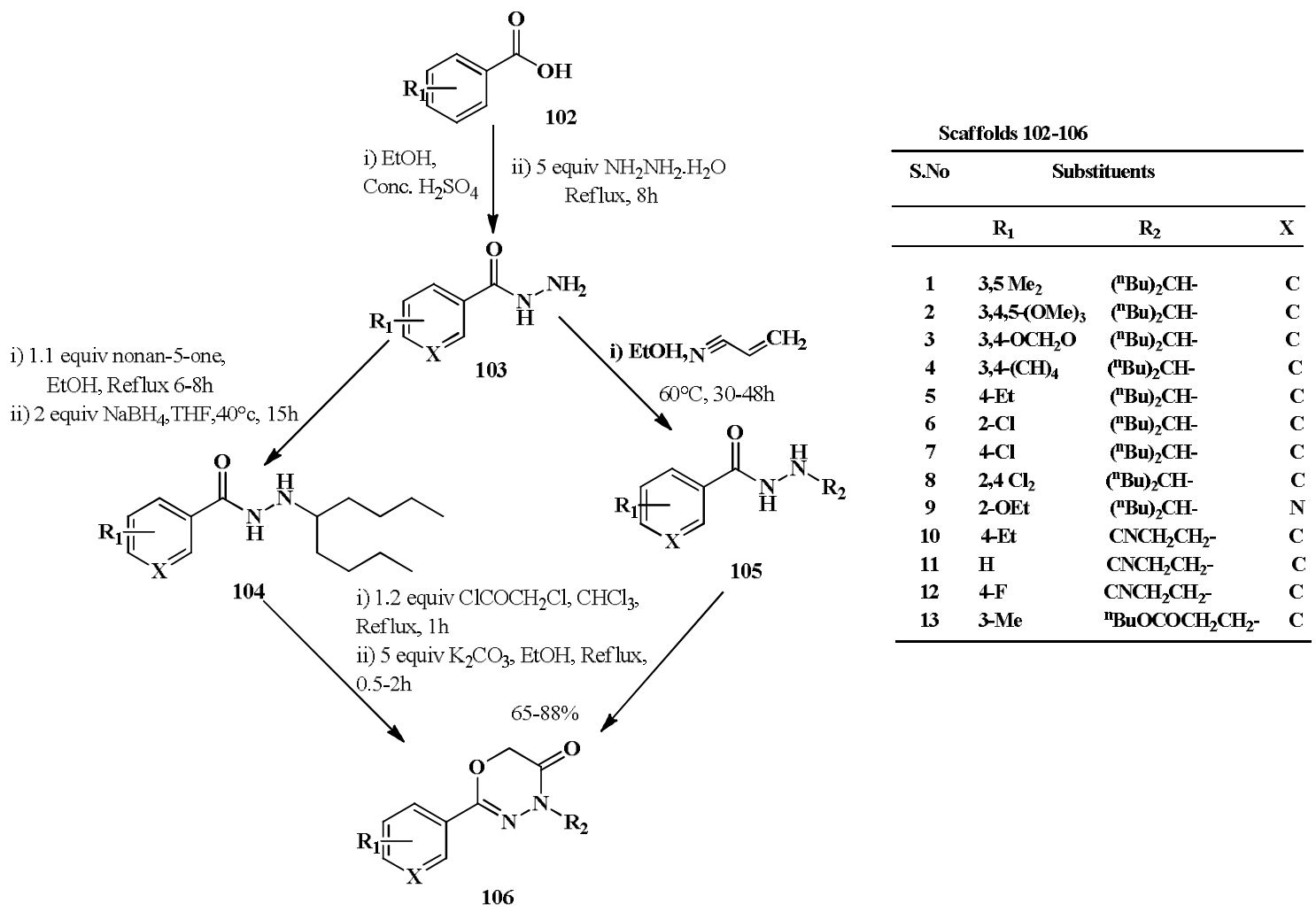

Scheme 28. Synthesis of some new $4 H$ 1,3,4-oxadiazin-5(6H)-ones with hydrophobic and long alkyl chains

Design of heterocycles from a common precursor (2RS,3SR)-2,3-dibromo-1,3-bis (4-fluorophenyl)- propan-1-one 107 with 4-Hydroxybenzo-hydrazide to give the 1,3,4-oxadiazine scaffolds $\mathbf{1 0 8}$ and $\mathbf{1 0 9}$ (Scheme 29) with two stereogenic centers ${ }^{41}$. 
<smiles>[R]C(=O)C(Br)C([R])Br</smiles>

$\mathrm{R}=4-\mathrm{FC}_{6} \mathrm{H}_{4}(64 \%)$

Scheme 29. Synthesis of 1,3,4-oxadiazines from 2,3-dibromo propan-1-one with stereogenic centers

Synthesis of a new series of scaffolds from substituted hydrazines $\mathbf{1 1 0}$ with diethyl oxalate $\mathbf{1 1 1}$ in ethanol to get an intermediate 112, which reacts with a solvent DMF in a basic condition to deprotonate the moderately acidic proton to form the cyclic scaffold by dihaloethane $\mathbf{1 1 3}$ to get the $N$-aryl-1,3,4oxadiazine-2-carboxylic acid 114 (Scheme 30). This scaffold further reacted with amine moieties of thiazoles to get carboxamides compounds which were screened towards antioxidant activity and DNA damage inhibition. All the synthesized scaffolds exhibited good antioxidant activities compared to standard and the compounds with electron donating groups on para position exhibited good DNA damage inhibition ${ }^{42}$.

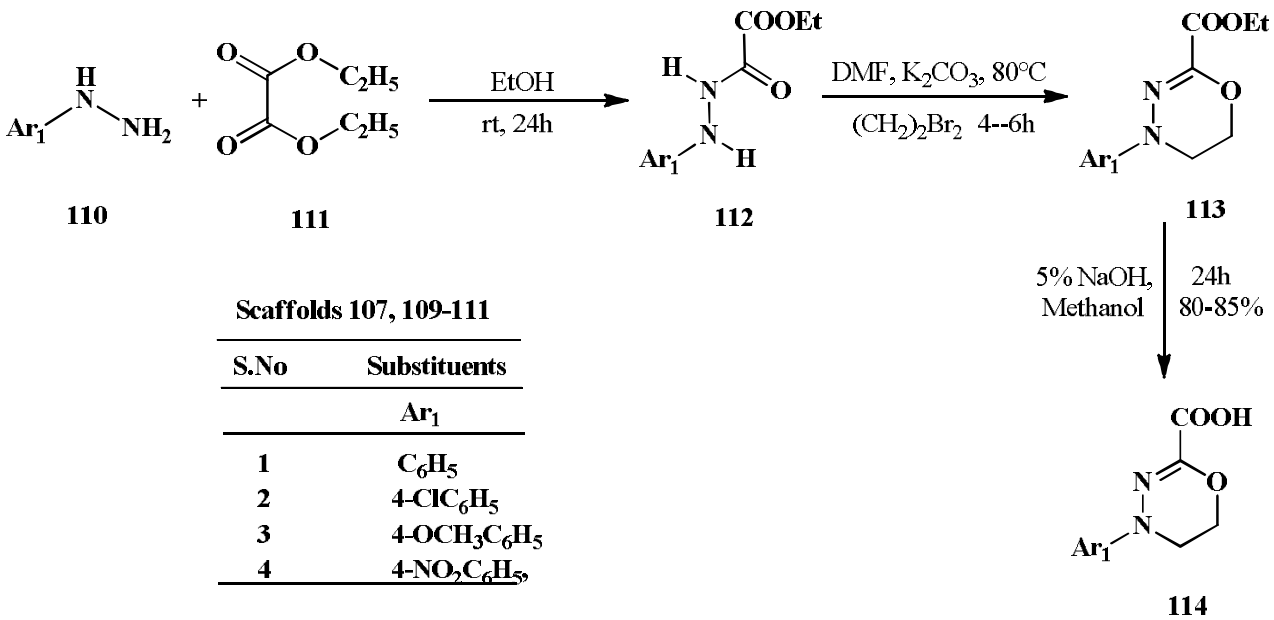

Scheme 30. Synthesis of substituted1,3,4-oxadiazines from substituted hydrazines and diethyl oxalate

Development of a spiro compound with functionalized propyl sulfonic acid SBA-15 mesoporous silica ( $\left.\mathrm{SBA}-\mathrm{Pr}-\mathrm{SO}_{3} \mathrm{H}\right)$ as an acid catalyst by solvent-free three-component reaction with hydrazide 115 cyclic ketones 116 cyclohexyl isocyanide 117 to obtain an unexpected scaffold ${ }^{43}$ of spirooxadiazine 119 (Scheme 31) rather than hydrazino amide 118.

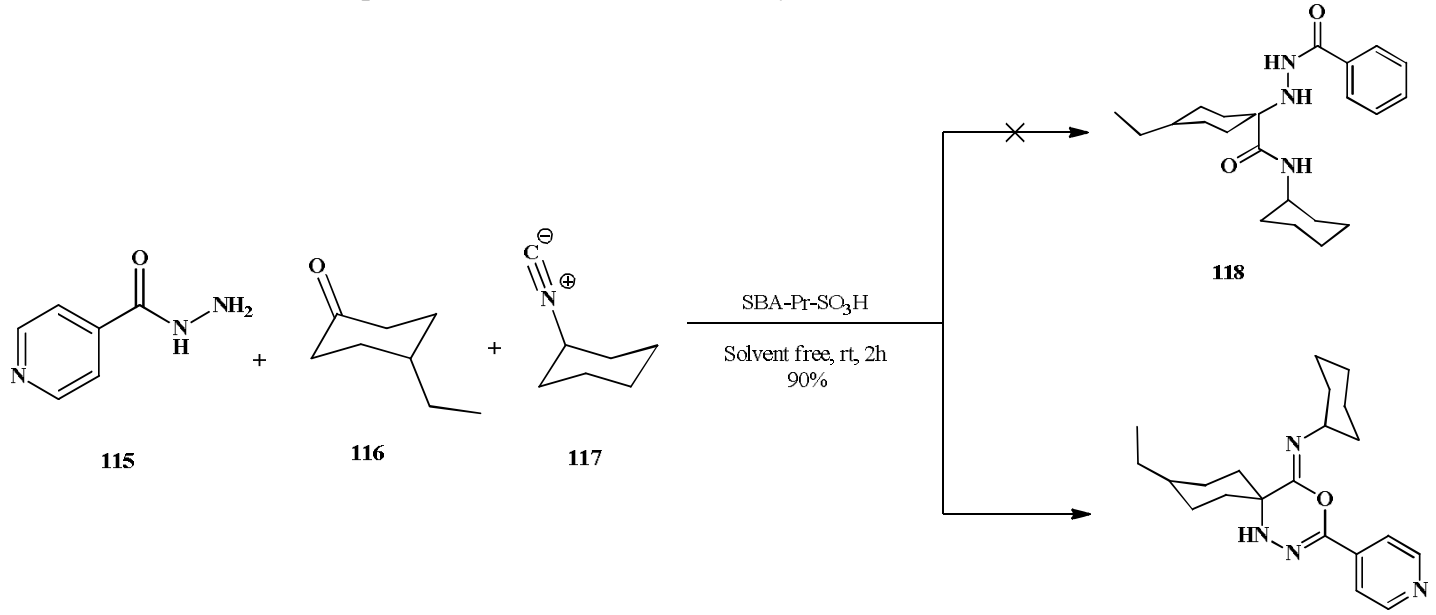

119

Scheme 31. Spirooxadiazines from three component reaction scaffold by acid catalyzed $\mathrm{SBA}-\mathrm{Pr}-\mathrm{SO}_{3} \mathrm{H}$ 
In 2011, developed a series of scaffolds with the help of two substituted diazine moieties 5-bromo-2,4-dichloro-6-methylpyrimidine $\mathbf{1 2 0}$ with $\mathrm{N}$-methylhydrazine in chloroform are converted into 5-bromo-2-chloro-4-methyl-6-(1-methyl-hydrazinyl)-pyrimidine 121 and 3,6-dichloro-4-(1-methylhydrazinyl) pyridazine 124 which on reacting with acyl halides in dry acetonitrile and bases $\left(\mathrm{K}_{2} \mathrm{CO}_{3}\right.$ and $\mathrm{NaNH}_{2}$ ) undergoes heterocyclization to obtain fused pyrimidine $\mathbf{1 2 5}$ and pyridazine $\mathbf{1 2 2}$ of 1,3,4oxadiazines. The obtained scaffolds further undergo condensation with secondary amines to form substituted products $\mathbf{1 2 3}$ (Scheme 32) and $\mathbf{1 2 6}$ (Scheme 33). Both the scaffolds show highest antimicrobial sensitivity when the electron donating groups or withdrawing groups are present in the paraposition ${ }^{44-45}$.<smiles>Cc1nc(Cl)nc(Cl)c1Br</smiles>

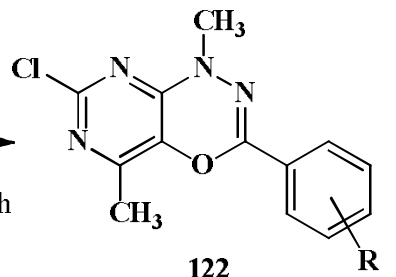

120

121

Scaffold 122

$\begin{array}{cc}\mathrm{R}=\mathbf{a}=\mathrm{H} & \mathbf{e}=4-\mathrm{Br} \\ \mathbf{b}=\mathbf{2 - C} & \mathbf{f}=3-\mathrm{NO}_{2} \\ \mathbf{c}=3-\mathrm{Cl} & \mathrm{g}=4-\mathrm{NO}_{2} \\ \mathbf{d}=4-\mathrm{Cl} & \mathbf{h}=4-\mathrm{CH}_{3} \\ \text { Scaffold 123 } & \end{array}$

$\mathbf{R}=\mathbf{H}$

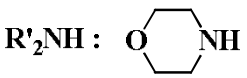
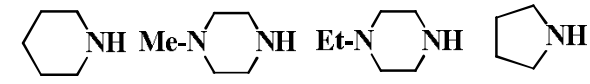<smiles>[R]c1ccc(C2=NN(C)c3nc([R4])nc(C)c3O2)cc1</smiles>

Scheme 32. Synthesis of fused 1,3,4-oxadiazines from substituted pyrimidine<smiles>[R]c1ccc(C2=NN(C)c3cc(Cl)nnc3O2)cc1</smiles>

Scaffold 125

$$
\begin{aligned}
\mathrm{R}=\mathrm{a} & =\mathrm{H} \\
\mathbf{b} & =\mathbf{2}-\mathrm{Cl} \\
\mathbf{c} & =\mathbf{3}-\mathrm{Cl} \\
\mathrm{d} & =\mathbf{4}-\mathrm{Cl}
\end{aligned}
$$

$$
\begin{aligned}
& \mathrm{e}=\mathbf{4}-\mathrm{Br} \\
& \mathrm{f}=\mathbf{3}-\mathrm{NO}_{2} \\
& \mathrm{~g}=\mathbf{4}-\mathrm{NO}_{2} \\
& \mathrm{~h}=\mathbf{4}-\mathrm{CH}_{3}
\end{aligned}
$$

Scaffold 126

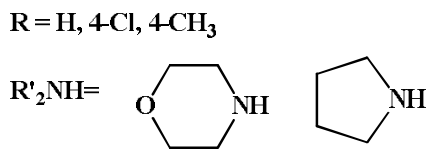

Scheme 33. Synthesis of fused 1,3,4-oxadiazines from substituted pyridazine.

Substituted groups like phenolic, $p$-toluenesulfonyl, indole acetate, benzyl, benzoyl of 127 which was treated with hydrazine hydrate in ethanol to afford hydrazides $\mathbf{1 2 8}$ with acrylonitrile to form 2-(2-cyanoethyl) hydrazides $\mathbf{1 2 9}$ which undergoes cyclization with chloroacetyl chloride in presence of potassium carbonate to attain a target of 5,6-dihydro-5-oxo-4H-1,3,4-oxadiazine6-4-propanenitriles 130 (Scheme 34) with good yields ${ }^{46}$. 


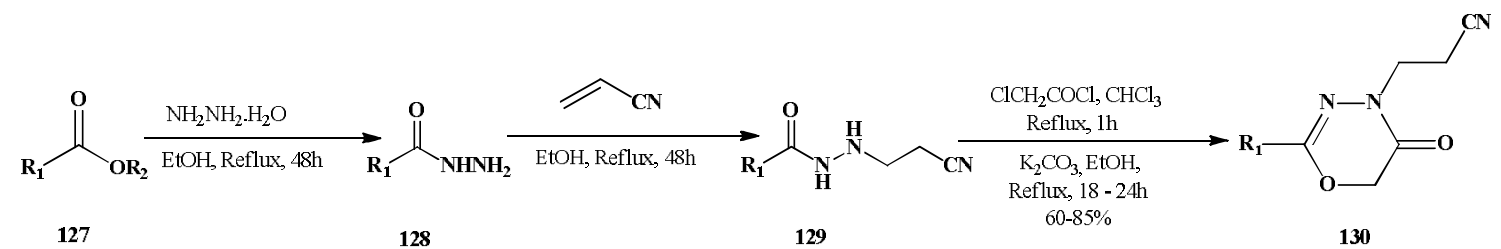

128

Scaffold 127

Scheme 34. Synthesis of substituted 1,3,4-oxadiazines 4-propanenitriles and their intermediates from an ester

A series of scaffolds from DMAP (4-dimethylaminopyridine)-catalyzed [2+4] cycloadditions of $(E)$-ethyl 4-phenylbut-2-enoate 131 with
$N$-acyldiazines 132A \& 132B undergoes cyclization to form a heterocyclic scaffold 1,3,4-oxadiazine 133A \& 133B (Scheme 35) with a low to high yields ${ }^{47}$. 


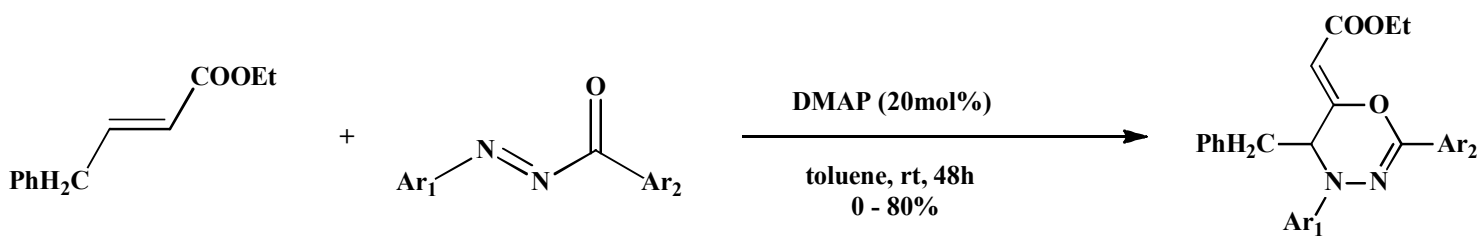

131

132 (A \& B)

133 (A \& B)

Scaffold 132 A \& 133 A

\begin{tabular}{lll}
\hline S.No & \multicolumn{2}{c}{ Substituents } \\
\hline & \multicolumn{1}{c}{$\mathrm{Ar}_{1}$} & $\mathrm{Ar}_{2}$ \\
\hline & & $\mathrm{Ph}$ \\
2 & $\mathrm{Ph}$ & $\mathrm{Ph}$ \\
3. & $4-\mathrm{MePh}$ & $\mathrm{Ph}$ \\
4 & $4-\mathrm{ClPh}$ & $\mathrm{Ph}$ \\
5 & $4-\mathrm{BrPh}$ & $\mathrm{Ph}$ \\
6 & $2-\mathrm{NO} \mathbf{2}_{2} \mathrm{Ph}$ & $\mathrm{Ph}$ \\
7 & $3-\mathrm{CIPh}$ & $\mathrm{Ph}$ \\
8 & $2,4(\mathrm{Cl})_{2} \mathrm{Ph}$ & $\mathrm{Ph}$ \\
9 & $3,4(\mathrm{Cl})_{2} \mathrm{Ph}$ & $\mathrm{Ph}$ \\
10 & $3,5(\mathrm{Cl})_{2} \mathrm{Ph}$ & $\mathrm{Ph}$ \\
& & \\
& & \\
\hline
\end{tabular}

Scaffold 132 B \& 133 B

\begin{tabular}{lll}
\hline S.No & \multicolumn{2}{c}{ Substituents } \\
& $\mathrm{Ar}_{1}$ & \multicolumn{1}{c}{$\mathrm{Ar}_{2}$} \\
\hline & & \\
\hline 1 & $\mathrm{Ph}$ & $4-\mathrm{MeOPh}$ \\
2 & $\mathrm{Ph}$ & $4-\mathrm{MePh}$ \\
3 & $\mathrm{Ph}$ & $4-\mathrm{FPh}$ \\
4 & $\mathrm{Ph}$ & $4-\mathrm{CIPh}$ \\
5 & $\mathrm{Ph}$ & $4-\mathrm{BrClPh}$ \\
6 & $\mathrm{Ph}$ & $4-\mathrm{NO} \mathrm{Ph}$ \\
7 & $\mathrm{Ph}$ & $2-\mathrm{MePh}$ \\
8 & $\mathrm{Ph}$ & $3,4-(\mathrm{MeO})_{2} \mathrm{Ph}$ \\
9 & $\mathrm{Ph}$ & $3,5-(\mathrm{MeO})_{2} \mathrm{Ph}$ \\
10 & $\mathrm{Ph}$ & $3,4,5-(\mathrm{MeO})_{3} \mathrm{Ph}$ \\
11 & $\mathrm{Ph}$ & $2-$ furanyl \\
12 & $\mathrm{Ph}$ & $1-$-naphthyl \\
& & \\
\hline
\end{tabular}

Scheme 35. Synthesis of 1,3,4-oxadiazines from DMAP- catalyzed [2+4] cycloadditions of (E)-ethyl 4phenylbut-2-enoate with $N$-acyldiazines.

Synthesis by $N$-arylhomophthalimides 134 which undergoes bromination at highly reactive methylene in cold acetic acid to get the monobromo derivatives 135 which is reacted with $\mathrm{N}$-phenylacetohydrazonic acid in basic condition to yield the scaffold of 1,3,4-oxadiazine 136 with an yield of 60$73 \%$ which is reacted with iodide (methyl/1- methylpyridinium/ methylquinolinium iodide) salts to yield monomethine cyanine dyes which on further reaction with picolinium or quinaldinium iodide salts to synthesize the trimethyl cyanine dyes. The compounds exhibit some moderate to high antibacterial activities (Scheme 36) ${ }^{48}$.<smiles>O=C(O)[14CH2]N1C(=O)Cc2ccccc2C1=O</smiles>

134<smiles>O=c1c2ccccc2c(Br)c(O)n1[Al]</smiles>

135
PhHN $_{\text {N }}$

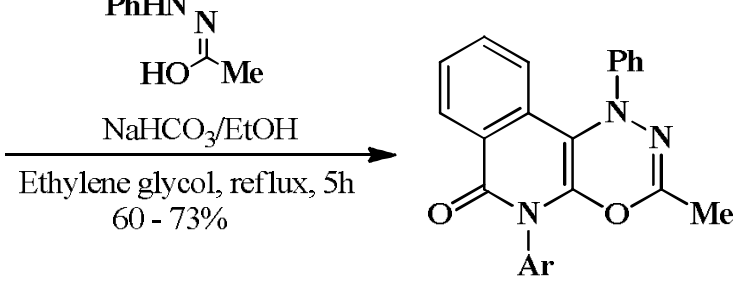

136

$$
\mathrm{Ar}=\mathrm{a}=\mathrm{Ph} ; \quad \mathrm{b}=4-\mathrm{MeOPh}
$$

Scheme 36. Synthesis of 1,3,4-oxadiazines from $N$-arylhomopthalimides

Three types of 1,3,4-oxadiazines from a substituted benzoic acid $\mathbf{1 3 7}$ which undergoes condensation with hydrazine and $\mathrm{N}$-methylhydrazine to obtain substituted benzoic acid hydrazide 138 and $N$-methylatedbenzoic acid hydrazide 141 which further reacted with 1-bromo-2-fluoroethane in a basic condition to get the one with unsubstituted 139 and two with substituted1,3,4-oxadiazines 140 and 142 (Scheme 37) ${ }^{49-50}$. 


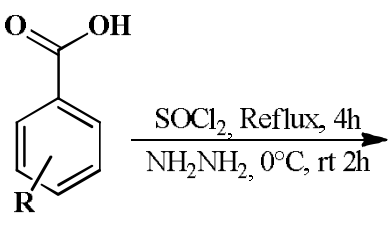

137

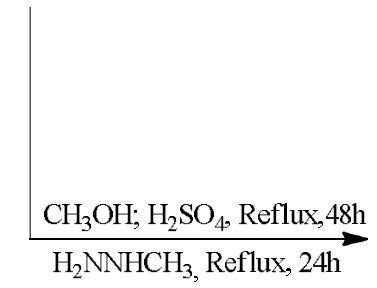

$\mathrm{R}=\mathrm{Br}$
138
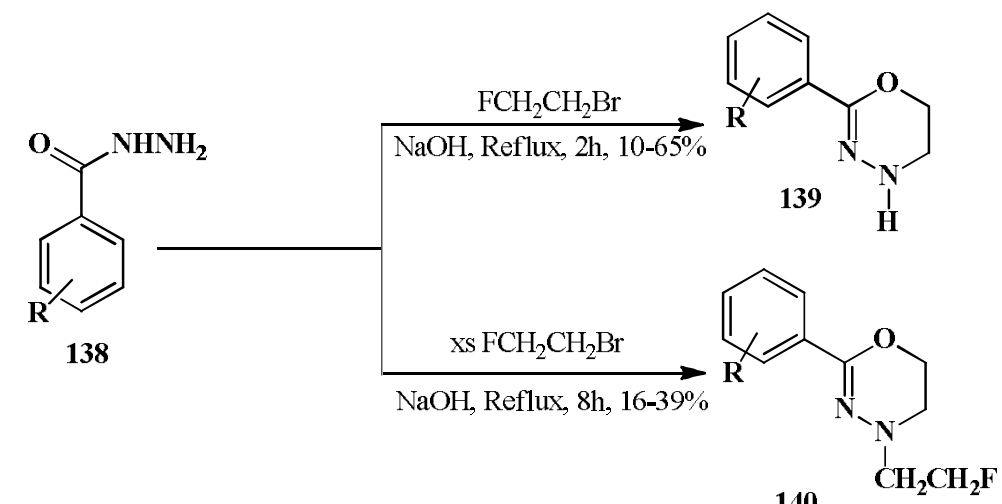

141<smiles>[R]c1cccc(C2=NN(C)CCO2)c1</smiles>

Scheme 37. Synthesis of 1,3,4-oxadiazines scaffolds from hydrazides and substituted hydrazides.

Bidentate nucleophile with $N$-Phenylbenzohydrazides 143 which lead to derivatives of different 145 quinoxalino 146 and pyridino $1474 H-1,3,4-$ benzooxadiazine 148 (Scheme 38) ${ }^{51}$. heterocyclic structures like pyrimido 144 pyrazino,

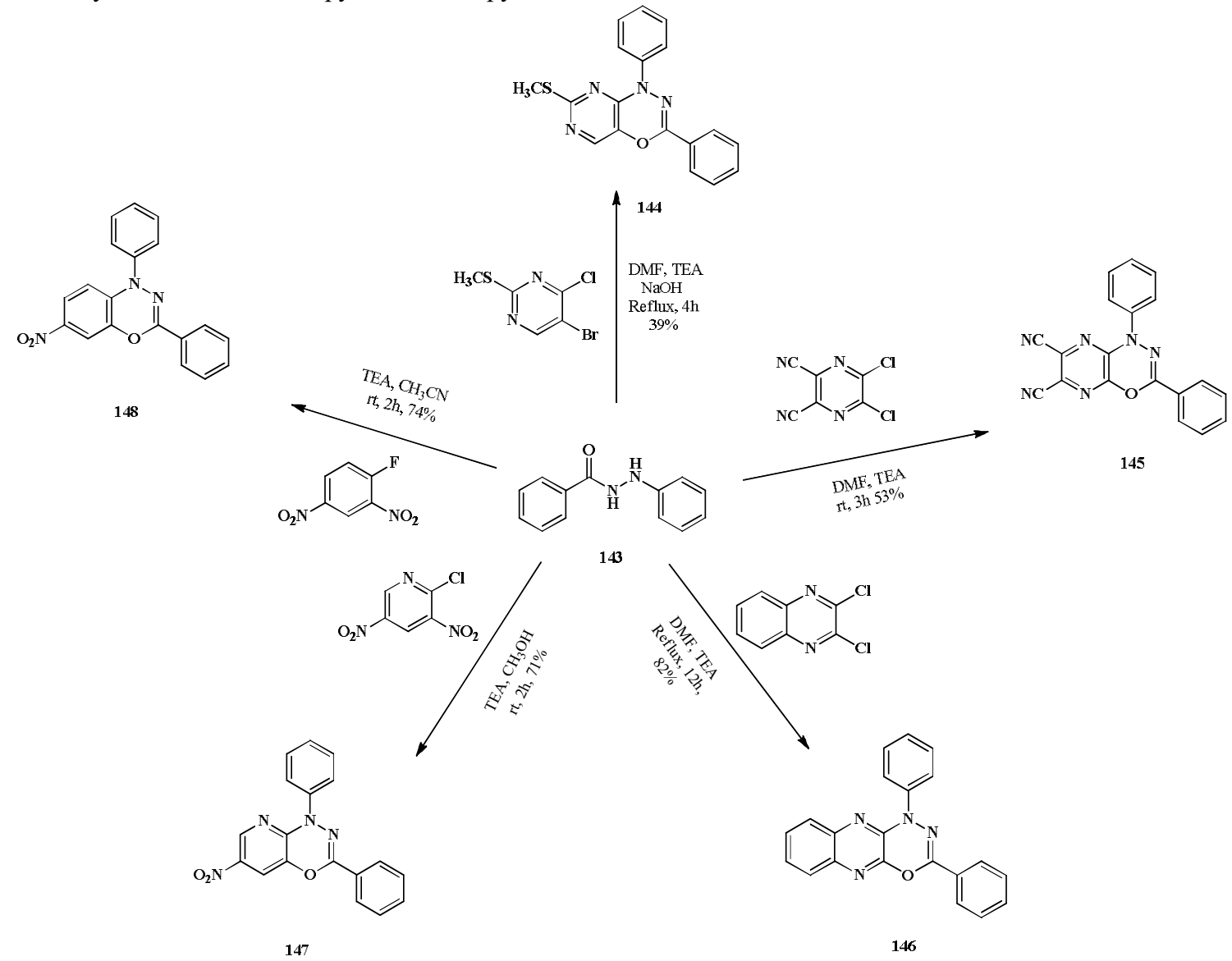

Scheme 38. Synthesis of different scaffolds of fused heterocyclic of 1,3,4-oxadiazines from $N$ phenylbenzohydrazides 
2-bromo-phenol 149 and 3-bromo-2-naphthol 150 of equimolar ratios and acid hydrazides derivatives were reacted by a conventional method with ethylene glycol containing $20 \% \mathrm{NaHCO}_{3}$ and green method with $20 \% \mathrm{NaHCO}_{3}$ under the solventfree condition at room temperature with good yield rather than the conventional method (Scheme 39) ${ }^{52}$.<smiles>Oc1cc2ccccc2cc1Br</smiles>

150
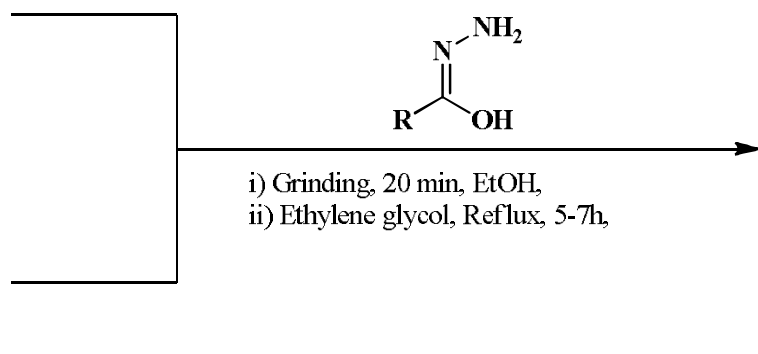

i) Grinding, $20 \mathrm{~min}, \mathrm{EtOH}$,

ii) Ethylene glycol, Reflux, 5-7h,
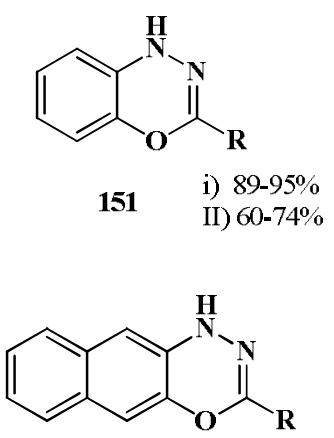

152 i) $88-94 \%$

ii) $59-71 \%$

Scheme 39. Green synthesis of 1,3,4-oxadiazines from acid hydrazides

\section{1, 3, 5-oxadiazine scaffolds}

A new class of 1,3,5-oxadiazine scaffolds 154

(Scheme 40) from $\alpha$-hydroxy isocyanates $\mathbf{1 5 3}$ in the presence of base pyridine which is obtained from isocyanic and carbonyl compounds ${ }^{53}$.

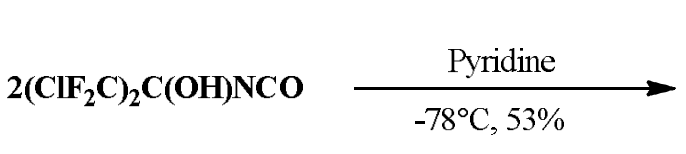

153

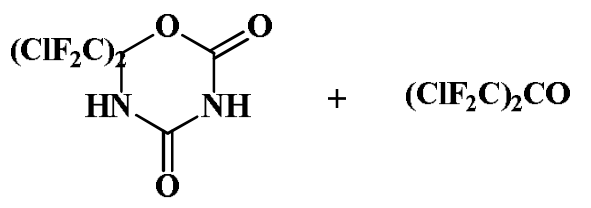

154

Scheme 40. Synthesis of 1,3,5-oxadiazines from $\alpha$-hydroxy isocyanates

Cyclization reaction with three moles of Benzoyl isocyanate $\mathbf{1 5 5}$ by taking 1-ethyl-3-methyl-3phospholene-1-oxide as a catalyst to form a substituted 1,3,5-oxadiazine scaffold $\mathbf{1 5 6}$ (Scheme 41 ) by the liberation of carbon dioxide with a yield ${ }^{54}$ of $68 \%$.

3

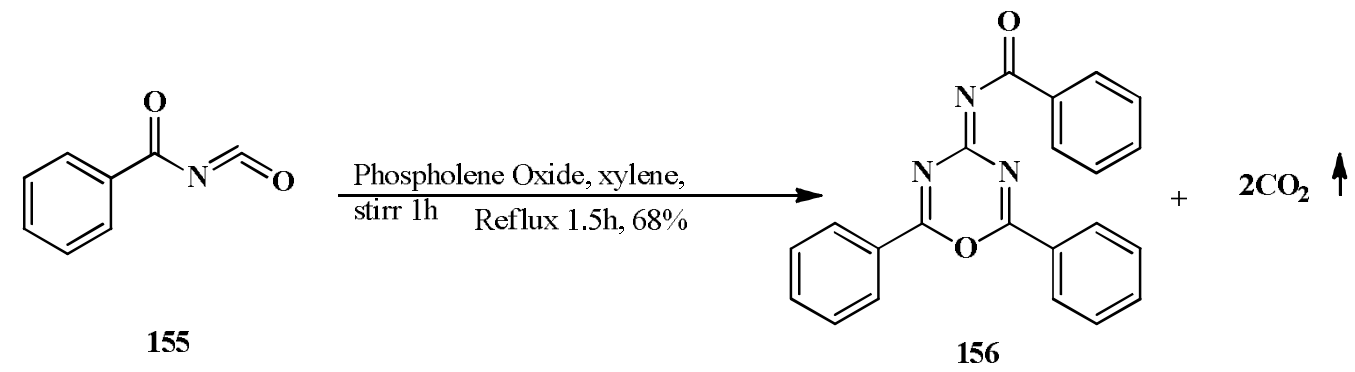

Scheme 41. Synthesis of 1,3,5-oxadiazines from benzoyl isocyanate

Substituted cyanamides 157 with perhaloacetones 158 gave corresponding 1,3,5-oxadiazine scaffolds
159 (Scheme 42) with good yield ${ }^{55}$. 


\begin{tabular}{|c|c|c|c|c|}
\hline \multirow{2}{*}{$2 \mathrm{R}_{2} \mathrm{NCN}$} & \multirow{2}{*}{+} & \multirow{2}{*}{$\mathbf{R}_{2}^{\prime} \mathbf{C}=\mathbf{O}$} & \multicolumn{2}{|c|}{ Reflux, $175^{\circ} \mathrm{C}$} \\
\hline & & & & $91 \%$ \\
\hline \multirow[t]{9}{*}{157} & & 158 & & \\
\hline & Scaff & Is $157-159$ & & \\
\hline & S.No & \multicolumn{3}{|c|}{ Substituents } \\
\hline & & $\mathbf{R}$ & & $\mathbf{R}^{\prime}$ \\
\hline & 1 & $\mathbf{H}$ & & $\mathrm{CF}_{3}$ \\
\hline & 2 & $\mathbf{H}$ & & $\mathrm{CF}_{2} \mathrm{Cl}$ \\
\hline & 3 & $\mathrm{CH}_{3}$ & & $\mathrm{CF}_{3}$ \\
\hline & 4 & $\mathrm{CH}_{3}$ & & \\
\hline & 5 & $\mathrm{CH}_{2}=$ & $\mathrm{CH}-\mathrm{CH}_{2}-$ & $\mathrm{CF}_{3}$ \\
\hline
\end{tabular}

Scheme 42. Synthesis of 1,3,5-oxadiazines from substituted cyanamides with perhaloacetones.

Design of 1,3,5-oxadiazine scaffold $\mathbf{1 6 2}$ cyanate $\mathbf{1 6 0}$ with an imine161with good yields ${ }^{56-60}$. (Scheme 43) from benzoyl isothiocyanate or thioiso-

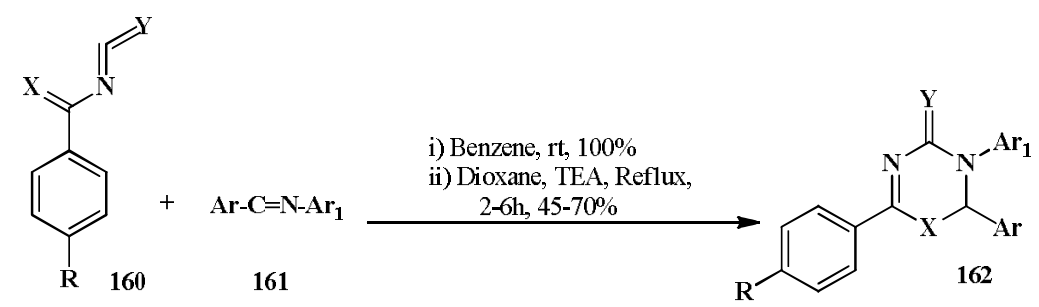

Scaffolds 160-162

\begin{tabular}{|c|c|c|c|c|c|}
\hline \multirow[t]{2}{*}{ S.No } & \multicolumn{5}{|c|}{ Substituents } \\
\hline & $\mathbf{R}$ & Ar & $\mathbf{A r}_{1}$ & $\mathrm{x}$ & $\mathbf{Y}$ \\
\hline 1 & $\mathbf{H}$ & $\mathrm{C}_{6} \mathrm{H}_{5}$ & $\mathrm{CH}_{2} \mathrm{C}_{6} \mathrm{H}_{5}$ & $\mathrm{O} / \mathrm{S}$ & o \\
\hline 2 & $\mathrm{OCH}_{3}$ & $\mathrm{C}_{6} \mathrm{H}_{5}$ & $\mathrm{CH}_{2} \mathrm{C}_{6} \mathrm{H}_{5}$ & $\mathrm{O} / \mathrm{S}$ & o \\
\hline 3 & $\mathbf{C l}$ & $\mathrm{C}_{6} \mathrm{H}_{5}$ & $\mathrm{CH}_{2} \mathrm{C}_{6} \mathrm{H}_{5}$ & $\mathrm{O} / \mathrm{S}$ & o \\
\hline 4 & $\mathrm{NO}_{2}$ & $\mathrm{C}_{6} \mathrm{H}_{5}$ & $\mathrm{CH}_{2} \mathrm{C}_{6} \mathrm{H}_{5}$ & O & o \\
\hline 5 & $\mathbf{H}$ & $\mathbf{H}$ & & o & $\mathbf{S}$ \\
\hline 6 & $\mathbf{H}$ & & $"$ & o & $\mathbf{S}$ \\
\hline 7 & $\mathbf{H}$ & & $"$ & O & $\mathbf{S}$ \\
\hline 8 & $\mathbf{H}$ & & $"$ & $\mathbf{O}$ & $\mathbf{S}$ \\
\hline 9 & $\mathbf{H}$ & & $"$ & o & $\mathbf{S}$ \\
\hline 10 & $\mathbf{H}$ & & $"$ & o & $\mathbf{S}$ \\
\hline 11 & $\mathbf{H}$ & ${ }_{3} \mathrm{CO}$ & $"$ & O & $\mathbf{S}$ \\
\hline 12 & H & 0 & $"$ & o & $\mathbf{S}$ \\
\hline
\end{tabular}


Scaffolds 160-162 Contd....

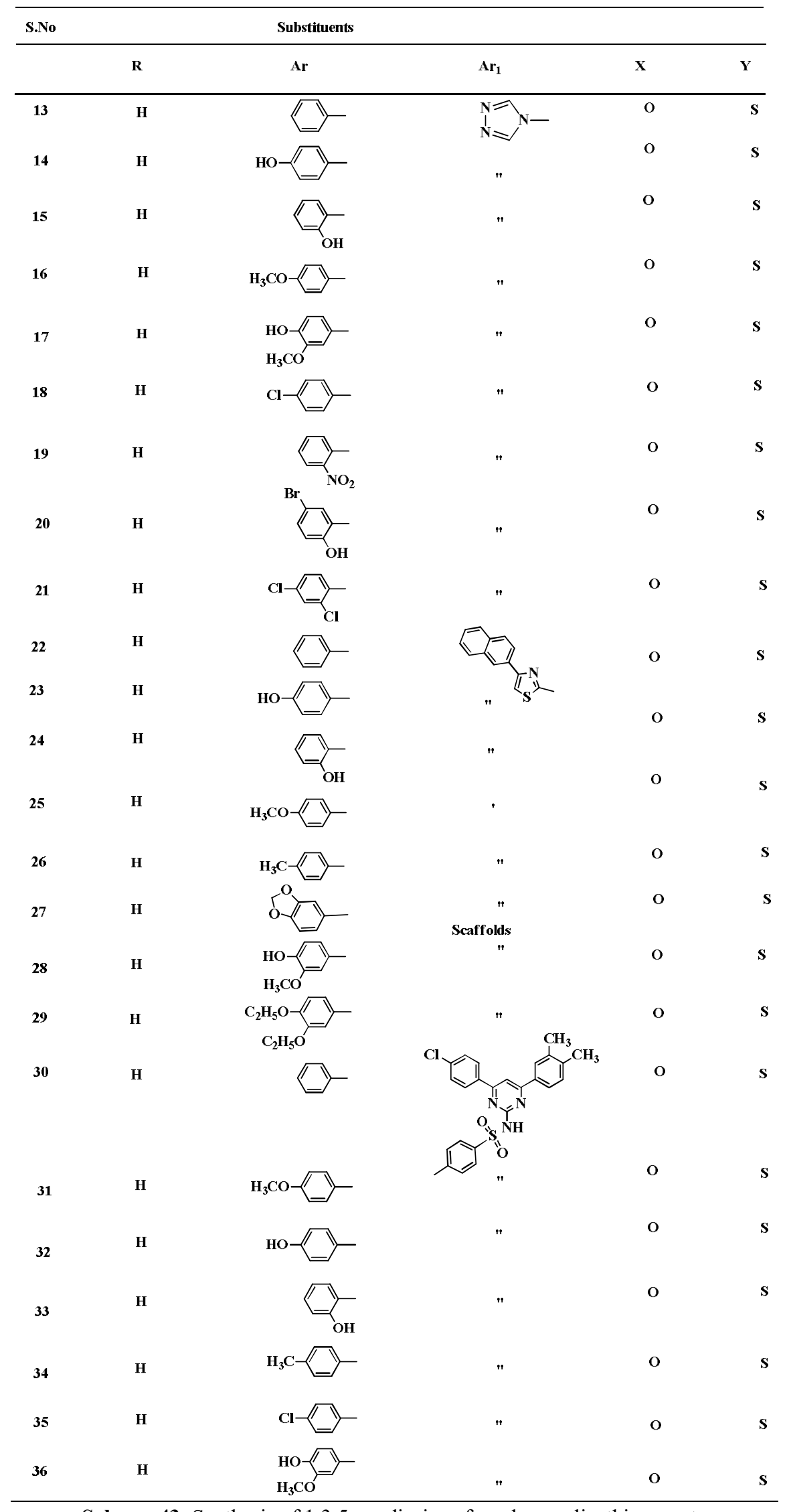

Scheme 43. Synthesis of 1,3,5-oxadiazines from benzoylisothiocyanate 
The reaction of urea or thiourea 163 with Acyl Chlorides 164 to form $N, N^{\prime}$-diaroyl urea/thiourea 165 which undergoes cyclization reaction with acetic anhydride to form Scaffolds of 1,3,5-oxadiazines 166 (Scheme 44 ) with a yield ${ }^{61}$ of $13-55 \%$.

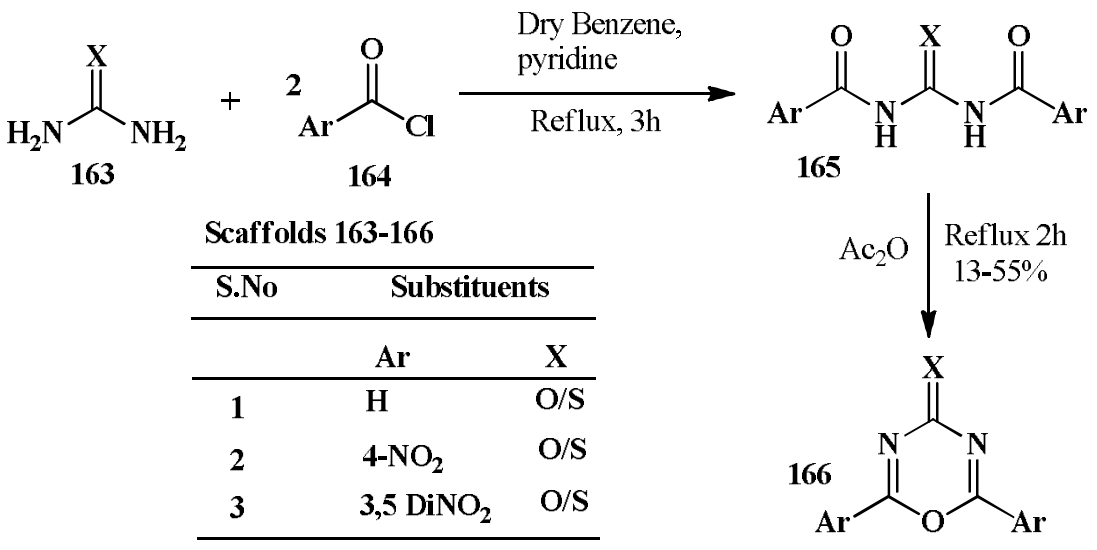

Scheme 44. Synthesis of 1,3,5-oxadiazines from urea/thiourea with acyl derivatives

4-Chloro- $N$-(2,2,2-trichloro-1-isothiocyanatoethyl)benzamide $\mathbf{1 6 7}$ with substituted aromatic amines $\mathbf{1 6 8}$ in polar solvent acetonitrile at room temperature to attain $N$-amidoalkylated thioureas 169 which undergoes reaction with DCC to form carbodiimide $\mathbf{1 7 0}$ and $\mathbf{1 7 1}$ which rearranges to form 1,3,5 scaffold 172 (Scheme 45) ${ }^{62}$.<smiles>O=C(NC(N=C=S)C(Cl)(Cl)Cl)c1ccc(Cl)cc1</smiles>

167<smiles>[R]c1c([R])c([R])c(N)c([R])c1[R4]</smiles>

168<smiles>[R]c1c([R4])c([R4])c(NC(=S)NC(NC(=O)c2ccc(Cl)cc2)C(Cl)(Cl)Cl)c([R4])c1[R]</smiles>

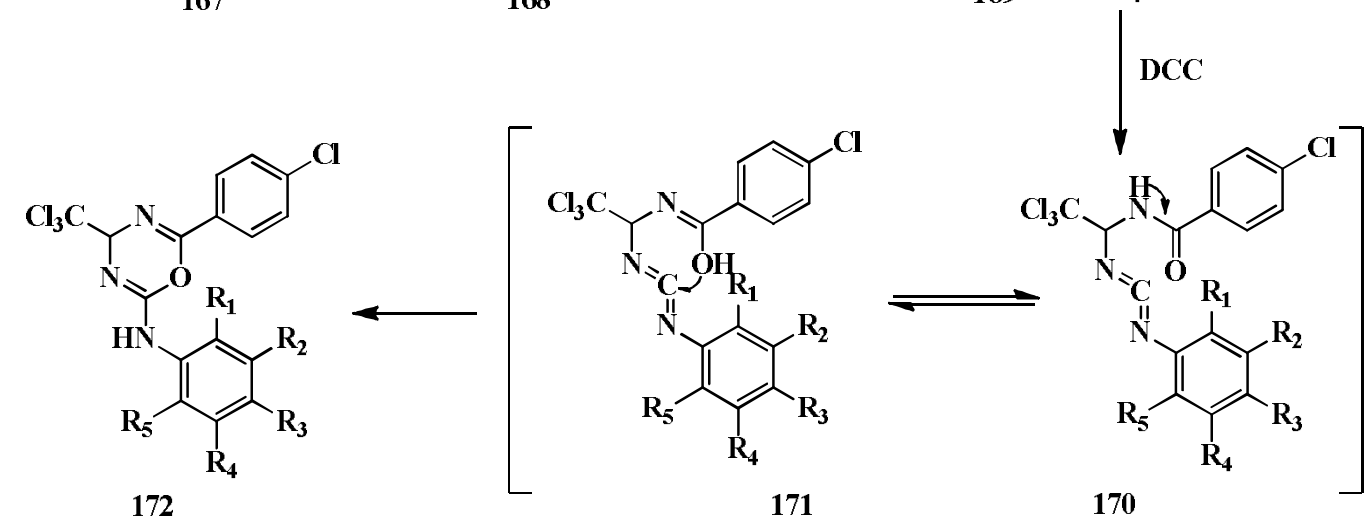

171
170

Scaffolds 167-172

\begin{tabular}{clllll}
\hline S. No & \multicolumn{5}{c}{ Substituents } \\
\hline & $\mathrm{R}_{1}$ & $\mathrm{R}_{2}$ & $\mathrm{R}_{3}$ & $\mathrm{R}_{4}$ & $\mathrm{R}_{5}$ \\
\hline $\mathbf{1}$ & $\mathrm{H}$ & $\mathrm{H}$ & $\mathrm{H}$ & $\mathrm{H}$ & $\mathrm{H}$ \\
$\mathbf{2}$ & $\mathrm{CH}_{3}$ & $\mathrm{H}$ & $\mathrm{CH}_{3}$ & $\mathrm{H}$ & $\mathrm{H}$ \\
$\mathbf{3}$ & $\mathbf{O C H}_{3}$ & $\mathrm{H}$ & $\mathrm{H}$ & $\mathrm{H}$ & $\mathrm{H}$ \\
$\mathbf{4}$ & $\mathrm{OCH}_{3}$ & $\mathrm{H}$ & $\mathrm{H}$ & $\mathrm{OCH}_{3}$ & $\mathrm{H}$ \\
$\mathbf{5}$ & $\mathrm{NO}_{2}$ & $\mathrm{H}$ & $\mathrm{CH}_{3}$ & $\mathrm{H}$ & $\mathrm{H}$ \\
$\mathbf{6}$ & $\mathrm{H}$ & $\mathrm{Br}$ & $\mathrm{H}$ & $\mathrm{H}$ & $\mathrm{H}$ \\
7 & $\mathrm{Cl}$ & $\mathrm{H}$ & $\mathrm{H}$ & $\mathrm{Cl}$ & $\mathrm{H}$ \\
$\mathbf{8}$ & $\mathrm{H}$ & $\mathrm{H}$ & $n B u O C(O)$ & $\mathrm{H}$ & $\mathrm{H}$ \\
\hline
\end{tabular}

Scheme 45. Synthesis of 1,3,5-oxadiazines from haloisothiocyanoalkyl benzamide 


\section{Conclusion}

Researchers made curiosity in developing the new scaffolds with six-membered heterocyclic rings with oxygen and two nitrogen atoms which have limited access. Oxadiazines made mounting interest in the development of scaffolds for targeting the diseased conditions. This review highlights the various synthetic protocols for the development of surplus and enormous scaffolds upon the different oxadiazines. There is a gigantic possibility of these scaffolds because of its different molecular targets. So far different pharmacological activities on some of the oxadiazines like antibacterial, antifungal, anthelmintic, anti-inflammatory, locomotor, anticonvulsive, antiviral, agricultural, antitumor insecticidal, nematocidal, miticidal, neurogenerative disorders like Alzheimer disease, blood disorder like anemia and plant regulation which have been discussed in synthetic part. Future investigations of this scaffold will give some promising results in the field of medicine. Advances of this field can be done to outcome the structure-activity relationship and mechanism of action of the particular compounds. This review gives great research ideas for the medicinal chemists to concentrate on these particular moieties for pharmacological activities in developing new scaffolds for their prominent effect on the real world.

\section{Conflicts of interest}

The authors declare no conflicts of interest.

\section{References}

1- T. Naito, Development of New Synthetic Reactions for Nitrogen-Containing Compounds and Their Application, Chem. Pharm. Bull.,2008, 56, 1367-1383.

2- N. R. Candeias, L. C. Branco, P. M. Gois, C. A. Afonso, A. F. Trindade, more sustainable approaches for the synthesis of $\mathrm{N}$ based heterocycles, Chem. Rev.,2009, 109(6), 2703-2802.

3- E. Lukevits, M. Shimanska, L. Leibs, I. Lovel, Catalytic synthesis and reactions of nitrogen heterocycles (review), Chem. Heterocycl. Compd., 1994, 30(11-12), 1284-1307.

4- T. Cam-Van, W. Jeffrey Bode, Synthesis of Saturated $N$-Heterocycles, J. Org. Chem., 2014, 79, 2809,-2815.

5- M. Amir, S. A. Javed, K. Harish, Synthesis of some 1, 3, 4-oxadiazole derivatives as potential anti-inflammatory agents, Indian J. Chem., 2007, 46B: 1014-1019.

6- O. Lopez, J. G. Fernandez-Bolanos, M. V. Gil, New trends in pest control: the search for greener insecticides, Green Chem., 2005, 7, 431-42.

7- D. Xu, X. Cai, S. Gong, Design, Synthesis and Evaluation of Insecticidal Activity of Novel
Oxadiazine Derivatives, Curr. Bioact. Compd.,2018, 14, 9-20.

8- A. A. Shetnev, F. I. Zubkov, The latest advances in chemistry of 1,2,4-oxadiazines (micro review), Chem. Heterocyl. Comp.,2017, 53(5), 495-497.

9- $\quad$ S. Ke, X. Cao, Y. Liang, K. Wang, Z. Yang, Synthesis and biological properties of dihydrooxadiazine-based heterocyclic derivatives, Mini-Rev. Med. Chem.,2011, 11(8), 642-657.

10 - H. S. Kim, Y. Kurasawa, Synthesis of 1,3, 4-thiadiazines and 1,3,4-oxadiazines, Heterocycles, 1998, 49(1), 557-586.

11- Sultanat, A. Ali, M. Asif, A. Rizvi, M. Farhan, S. Zaman, Discovery of a novel oxadiazine derivative of glucocorticoids endowed with DNA binding activities and molecular docking studies, J. Taibah Univ. Sci., 2019, 13(1), 536-546.

12- K. Voracova, J. Hajek, J. Mares, P. Urajova, M. Kuzma, J. Cheel, A. Villunger,

A. Kapuscik, M. Bally, P. Nova, M. Kabela, G. Krumschnabel, M. Lukes, L. Voloshko, J. Kopecky, P. Hrouzek, The cyanobacterial metabolite nocuolin A is a natural oxadiazine that triggers apoptosis in human cancer cells, PLoS One, 2017, 12(3), e0172850.

13- T. Bergmann, D. Schories, B. Steffan, Alboinon, an oxadiazinone alkaloid from the ascidian Dendrodagrossularia, Tetrahedron, 1997, 53(6), 2055-2060.

14- I. T. Kay, I. T. Streeting, A Simple Synthesis of 4-Dimethylamino-2-oxo-2H-1,3,5-oxadiazines, Synthesis, 1976, 1, 38.

15- K. D. Wing, M. E. Schnee, M. Sacher, Connair, A novel oxadiazine insecticide is bioactivated in lepidopteran larvae, Arch. Insectbiochem. Physiol., 1998, 37, 91-103.

16- L. Bruno, F. Grolleau, D. B. Sattelle, Indoxcarb an oxadiazine insecticide, blocks insect neuronal sodium channels, Br. J. Pharmacol., 2001, 132(2), 587-595.

17- D. Xu, J. Guan, X. Xu, S. Gong, H. Xu, A New Method for the Synthesis of Oxadiazine Insecticide Indoxacarb, J. Heterocyl. Chem.,2016, 53, 1469-1473.

18- P. Rajagopalan, C. N. Talaty, A New Synthesis of 1,2,4-oxadiazine derivatives from 1-aroylaziridine oximes, J. Am. Chem. Soc., 1966, 88(21), 5048-5049.

19- M. A. Calcagno, H. W. Heine, C. Kruse, W. A. Kofke, The synthesis and reactions of 4-aroyltetrahydro- 2H-1,2,4-oxadiazines, J. Org. Chem., 1974, 39(2), 162-166.

20- Z.-Y. Sun, T. Asberom, T. Bara, C. Bennett, D. Burnett, I, Chu, J. Clader, C.-W. Mary, D. Cole, M. Czarniecki, J. Durkin, G. Gallo, W. Greenlee, H. Josien, X. Huang, L. Hyde, N.Jones, I. Kazakevich, H. Li, X. Liu, J. Lee, M. MacCoss, M. B. Mandal, T. McCracken, A. Nomeir, R. Mazzola, A. Palani, E. M. 
Parker, D. A. Pissarnitski, JunQin, L. Song, G. Terracina, M. Vicarel, J. Voigt, R. Xu, L. Zhang, Q. Zhang, Z. Zhao, X. Zhu, Z. J. Zhu, Cyclic Hydroxyamidines as Amide Isosteres: Discovery of Oxadiazolines and oxadiazines as potent and highly efficacious $\gamma$ Secretase modulators invivo, Med. Chem., 2012, 55, 489-502.

21- X. Huang, W. Zhou, X. Liu, H. Li, G. Sun, M. Mandal, M. Vicarel, X. Zhu, C. Bennett, T. McCracken, D. Pissarnitski, Z. Zhao, D. Cole, G. Gallo, Z. Zhu, A. Palani, R. Aslanian, J. Clader, M. Czarniecki, W. Greenlee, D. Burnett, M. Cohen-Williams, L. Hyde, L. Songs, L. Zhang, I. Chu, A. Buevich, Synthesis and SAR studies of fused oxadiazines as $\gamma$-Secretase modulators for the treatment of Alzheimer's Disease, Med. Chem. Lett., 2012, 3, 931-935.

22- S. R. Pathipati, V. Singh, L. Eriksson, N. Selander, Lewis acid catalyzed Annulation of nitrones with oxiranes, aziridines and Thiiranes, Org. Lett., 2015, 17(18), 4506-4509.

23- S. P. Miller, W. J. Morris, R. K. Orr, J. Eckert, J. Milan, M. Maust, C. Cowden, J. Cui, Synthesis of the $\gamma$ - Secretase Modulator MK8428, J. Org. Chem., 2017, 82(6), 2957-2964.

24- X. Li, Z. Zhang, W. Wei, H. Chang, W. Gao, CN Patent 105461651.

25- A. Yuanyuan, X. Hongguang, W. Jie, Basecontrolled [3+3] cycloaddition of isoquinoline $\mathrm{N}$-oxides with azaoxyallyl cations, Chem. Commun., 2016, 52, 10415-10418.

26- L.-B. Zhang, X.-Q. Hao, Z.-J. Liu, X.X. Zheng, S.-K. Zhang, J.-L. Niu, M.-P. Song, Cobalt(II) catalysed $\mathrm{Csp}^{2}-\mathrm{H}$ Alkynylation/Annulation with terminal alkynes: Selective access to 3-methyleneisoindolin-1-one, Angew. Chem. Int. Ed., 2015, 54(34), 10012-10015.

27- S. Crotti, F. Berti, M. Pineschi, CopperCatalyzed perkin-Acyl-Mannich reaction of acetic anhydride with pyridine: Expeditious entry to unconventional piperidines, Org. Lett., 2011, 13(19), 5152-5155.

28- A. F. Trindade, J. W. Bode, Irreversible conjugation of aldehydes in water to form stable 1,2,4-oxadiazinan- 5-ones, Org. Lett., 2016, 18(17), 4210-4213.

29- H. Y. Song, Y. L. Cho, D. Y. Lee, H. S. Park, S. Y. Baek, S. E. Chae, S. H. Jo, Y. O. Kim, H. S. Lee, J. H. Park, T. K. Park, S. H. Woo, Y. Z. Kim, US Patent 20110112083.

30- W. Gangqiang, R. Chen, S. Zhao, L. Yang, H. Guo, S. Sun, J. Wang, J. Domena, Y. Xing, Efficient synthesis of 1,2,4-oxadiazine-5-ones via $[3+3]$ cycloaddition of in situ generated azaoxyallylic cations with nitrile oxides, Tetrahedron Lett., 2018, 59(21), 20182020.

31- A. Mustafa, W. Asker, A.H. Hurhash, M. A. E. Khalifa, E. M. Zayed, The behavior of oxazoline-(5) and thiazolinone-(5) against $N$-Phenyl hydroxyl amine and Phenyl hydrazine, Liebigs Ann. Chem., 1968, 713, 151-161.

32- M. Barbar, S. Kraljevi, M. Grce, B. Zorc, Novel 1,2,5-oxadiazine Derivatives-Synthesis and Invitro Biological studies, Acta Pharm, 2003, 53, 175-186.

33- E. A. Chugunovaa, N. I. Akylbekovb, N. V. Gavrilovb, V.A. Samsonovc, S. A. Sitnovd, A. B. Dobrynina, M. A., Pudovika, A. R. Burilova, Synthesis of new $3 H$-benzo[1,2,5] oxadiazine-4-oxide, Russ. J. Gen. Chem., 2016, 86(11), 2548-2550.

34- R. M. Mohareb, R. A. Ibrahim, H. E. Moustafa, Hydrazide-hydrazones in the synthesis of 1,3,4oxadiazine, 1,2,4- Triazine and pyrazole derivatives with antitumor activities, Open Org. Chem., J., 2010, 4(2), 08-14.

35- R. M. Mohareb, A. A. El-Khair, Novel synthesis of hydrazide-hydrazone and their uses for the synthesis 1,3,4-oxadiazine, 1,2,4triazine, pyrazole and pyridazine derivatives with antimicrobial and antifungal activities, Int. J Appl. Biol. Pharm.,2011, 2, 434-446.

36- M. L. Tintas, A. P. Diac, A. S. A. Terec, I. Grosu, E. Bogdan, Structural Characterization of new 2-aryl 5-phenyl-1,3,4oxadiazin-6-ones and their $\mathrm{N}$-aroylhydrazone precursors, J. Mol. Struct., 2014, 1058, 106-113.

37- V. Thirupathaiah, K. Suhasini, T. V. Padmanabha Rao, Synthesis of 2, 6-diaryl-4H1,3,4-oxadiazines as antibacterial agents, Curr. Sci., 1983, 52, 1133-1135.

38- K. Srinivas, T. Soujanya, Synthesis of some new 1,3,4 oxadiazine-[6,5-b] indole derivatives and their biological activity, Afr. J. Pharm Pharmacol., 2014, 8(25), 701-705.

39- N. N. Karade, J. M. Kondre, S. V. Gampawar, S. V. Shinde, Synthesis of 2,5-disubstituted 1,3,4-oxadiazine and 1,3,4-thiadiazine from substituted acetophenones and acid hydrazides using [Hydroxyl(tosyloxy)iodo] benzene, Synth. Commun., 2009, 39, 2279-2287.

40- Q. Yang, S.-Y. Ke, X.-H. Qian, F.-Y. Liu, Z. Li, Novel 4H-1,3,4-oxadiazin-5(6H)-ones with hydrophobic and long alkyl chains: design, synthesis and bioactive diversity on inhibition of monoamine oxidase, chitin biosynthesis and tumor cell, Eur. J. Med. Chem., 2009, 44, 2113 2121.

41- S. Samshuddin, J. P. Jasinski, J. A. Golen, B. Narayana, H. S. Yathirajan, C. Glidewell, Hydrogen-bonded chains in 3,5-bis(4fluorophenyl)-1- phenyl-1 $H$-pyrazole and complex hydrogen-bonded sheets in (5RS,6SR)-6-(4-fluorobenzoyl)-5-(4fluorophenyl)-2-(4-hydroxyphenyl)-5,6-dihydro $4 H-1,3,4$-oxadiazine 
$N, N$-dimethylformamidemonosolvate, Acta Cryst., 2014, C70 (9), 867-871.

42- K. Shubakara, K. B. Umesha,

N. Srikantamurthy, J.Chethan, Antioxidant and DNA damage inhibition activities of 4-aryl-N(4-aryl-thiazol-2-yl)-5,6-dihydro-4H-1,3,4oxadiazine-2-carboxamides, J. Chem. Sci.,

2014, 126(6), 1913-1921.

43- V. F. Vavsari, G. M. Ziarani, S. Balalaie, A. Badiei, F. G. Mohammadi, S. Ramezanpour, F. Rominger, Unexpected synthesis of 1,3,4oxadiazines using the extraordinary effect of SBA-Pr-SO ${ }_{3} \mathrm{H}$ as a nano catalyst. Chemistry Select, 2017, 2, 3496-3499.

44- M. Bakavoli, M. Rahimizadeh, A. Shiri, H. Eshghi, S. Vaziri-Mehr, P. Pordeli, M. Nikpour, Synthesis and evaluation of the anti bacterial activity of new derivatives of pyrimido[4,5-e][1,3,4]oxadiazine, Heterocycl.

Commun., 2011,17, 49-52.

45- M. Bakavoli, M. Rahimizadeh, A. Shiri, H. Eshghi, P. Pordeli, M. Pordel, M. Nikpour, Synthesis and antibacterial Evaluations of new pyridazino[4,3-e][1,3,4]oxadiazines, J. Heterocycl. Chem., 2011, 48, 149- 152.

46- K. M. Khan, S. Rahat, M. I. Choudhary, Attaur-Rahman, U. Ghani, S. Perveen, S. Khatoon, A. Dar, A. Malik, Synthesis and biological screening of 2-substituted 5,6-dihydro-5-oxo4H-1,3,4-oxadiazine-4- propanenitriles and of their intermediates, Helv.Chim. Acta, 2002, 85, 559-570.

47- Q. Zhang, L.-G. Meng, J. Zhang, L. Wang, DMAP-catalyzed [2+4]cycloadditions of allenoates with $N$ - Acyldiazines: Direct method to 1,3,4-oxadiazine derivatives, Org. Lett., 2015, 17(13), 3272-3275.

48- F. M. Eissa, A. R. Abdelghany, New 1,3,4oxadiazinoisoquinoline methane cyanine dyes: Synthesis photosensitivity and antibacterial activity, J. Heterocycl. Chem., 2016, 53(2), 429-436.

49- M. A. Dekeyser, W. A. Harrison, P. T. McDonald, G. W. Angle, Jr. S. M. M. Ismail, R. G. H. Downer, Computer-Aided Molecular Design; C. H. Reynolds, M. K. Holloway, K. Harold Cox, ed. ACS Symposium series, American chemical society, 1995, 589, 183-195.

50- M. A. Dekeyser, W. A. Harrison, P. T. McDonald, R. G. H. Downer, Design and Synthesis of 5,6-dihydro-4H-1,3,4-oxadiazines as potential octopaminergic insecticides, Pestic. Sci., 1993, 38, 309-314.

51- A. J. Elliott, Hydrazides and Thiohydrazides as sources of condensed oxadiazines and
Thiadiazines, including novel azo derivatives based on dithizone, J. Org. Chem.,1980, 45, 3677-3681.

52- Eissa, M. Fayez, Green Synthesis, Antibacterial, and Antifungal Activities of 1,3, 4-Oxadiazines, J. Heterocycl. Chem., 2018, 55(6), 1479-1483.

53- F. W. Hoover, H. B. Stevenson, H. S. Rothrock, Chemistry of isocyanic acid. I. Reactions of isocyanic acid with carbonyl compounds, J. Org. Chem., 1963, 28(7), 1825-1830.

54- L. A. McGrew, W. Sweeny, T. W. Campbell, V. S. Foldi, Reaction of Benzoyl isocyanate with a phospholene oxide catalyst, J. Org. Chem., 1964, 29(10), 3002-3004.

55- M. E. Hermes, R. A. Braun, Oxadiazines and dioxazines from perhaloacetones and cyanamides, J. Org. Chem., 1966, 31(8), 2568-2571.

56- O. Tsuge, M. Tashiro, R. Mizuguchi, S. Kanemasa, Dipolar cycloadditions reaction of benzoyl and thiobenzoyl isocyanates, Chem. Pharm. Bull., 1966, 14(9), 1055-1057.

57- H. S. Patel, K. B. Patel, Synthesis and biological activity of 3-[4H-(1,2,4)-Triazolyl]2,6-diaryl-1,3,5- oxadiazine-4-thione, Phosphorous, Sulfur Silicon Relat. Elem., 2009, 184(9), 2443-2452.

58- K. H. Patel, A. G. Mehta, Synthesis and antifungal activity of [(4-(2-naphthalenyl) thiazol-2-yl)-2-(substituted phenyl)-6-phenyl4-thioxo-1,3,5-oxadiazine] derivatives, Der Chemica Sinica, 2012, 3(6), 1410- 1414.

59- N. Rambabu, D. Ramachandran, B. M. Viral, J. G. Kirti, Synthesis, characterization and biological evaluation of 2,6-diphenyl-3-(4-(3phenyl-[1,2,4,]triazolo[3,4-b][1,3,4]thiadiazol6-yl)phenyl)-2H-1,3,5- oxadiazine-4(3H)thione, Der Pharma Chemica, 2012, 4(2), 639-643.

60- N. Rambabu, B. M. Viral, J. G. Kirti, Synthesis, characterization and biological evaluation of 2,6-diphenyl- 3-(4-(3-phenyl$[1,2,4$, ]triazolo[3,4-b] $[1,3,4]$ thiadiazol-6yl)phenyl)-2H-1,3,5-oxadiazine-4(3H)-thione, Der Pharma Chemica, 2012, 4(1), 511-516.

61- S. K. Younis, B. A. Ahmed, Synthesis of some new 1,3,5-oxadiazine derivatives, Raf. Jour. Sci., 2008, 19(3), 10-17.

62- V. Z. Pavlo, V. K. Vadym, O. P. Ihor, V. K. Aleksandr, A new method for the synthesis of $4 H-1,3,5-$ oxadiazine derivatives, Heterocycl. Commun.,2017, 23(5), 369-374. 


\begin{tabular}{|c|c|}
\hline HFIP & hexafluoro-2-propanol \\
\hline $\mathrm{DCC}$ & $N, N$ '-Dicyclohexylcarbodiimide \\
\hline $\mathrm{rt}$ & Room Temperature \\
\hline $\mathrm{THF}$ & Tetrahydrofuran \\
\hline $\mathrm{NaOMe}$ & Sodium methoxide \\
\hline $\mathrm{Cbz} \mathrm{NH}_{2}$ & Benzyl Carbamate \\
\hline $\mathrm{NaOH}$ & Sodium Hydroxide \\
\hline tert & Tertiary \\
\hline$i \mathrm{PrOH}$ & Isopropyl Alcohol \\
\hline$(\mathrm{DHQ})_{2} \mathrm{PHAL}$ & Hydroquinine 1,4-phthalazinediyl diether \\
\hline $\mathrm{K}_{2} \mathrm{OsO}_{2}(\mathrm{OH})_{4}$ & Potassium Osmate \\
\hline EDCI & 1-Ethyl-3-(3-dimethylaminopropyl)carbodiimide \\
\hline HOBT & Hydroxybenzotriazole \\
\hline DIEA & N, N-Diisopropylethylamine \\
\hline DMF & Dimethylformamide \\
\hline $\mathrm{PPh}_{3}$ & Triphenylphosphine \\
\hline DIAD & Diisopropyl azodicarboxylate \\
\hline $\mathrm{NH}_{2} \mathrm{NH}_{2}$ & Hydrazine \\
\hline $\mathrm{P}_{2} \mathrm{O}_{5}$ & Phosphorus Pentoxide \\
\hline $\mathrm{AlCl}_{3}$ & Aluminium trichloride \\
\hline $\mathrm{InCl}_{3}$ & Indium chloride \\
\hline $\mathrm{CH}_{3} \mathrm{CN}$ & Acetonitrile \\
\hline $\mathrm{CH}_{2} \mathrm{Cl}_{2}$ & Dichloromethane \\
\hline $\mathrm{Ph}$ & Phenyl \\
\hline $\mathrm{Bn}$ & Benzyl \\
\hline $\mathrm{h}$ & Hour \\
\hline $\mathrm{K}_{2} \mathrm{CO}_{3}$ & Potassium Carbonate \\
\hline$\left(\mathrm{CH}_{3}\right)_{2} \mathrm{SO}_{4}$ & Dimethylsulphate \\
\hline NH4OAc & Ammonium Acetate \\
\hline $\mathrm{MnO}_{2}$ & Manganese dioxide \\
\hline Red-Al & Sodium bis(2-methoxyethoxy)aluminium dihydride \\
\hline TFA & Trifluoroacetic acid \\
\hline$t-B u \mathrm{OK}$ & Potassium tert-butoxide \\
\hline $\mathrm{NADH}$ & Nicotinamide adenine dinucleotide \\
\hline GDH & Glucose dehydrogenase \\
\hline L-AADH & Aromatic amine dehydrogenase \\
\hline $\mathrm{NABH}_{4}$ & Sodium Borohydride \\
\hline iPrMgCl-LiCl & Isopropyl magnesium chloride-lithium chloride \\
\hline $\mathrm{iPr}_{2} \mathrm{NEt}$ & $N, N$-Diisopropyl Ethylamine \\
\hline $\mathrm{MsCl}$ & Methane Sulfonyl chloride \\
\hline HMDS & Hexamethyldisilazane \\
\hline TMSOTf & Trimethylsilyltrifluoromethanesulfonate \\
\hline $\mathrm{BtH}$ & Benzotriazole \\
\hline SAR & Structure Activity Relationship \\
\hline
\end{tabular}

